\title{
Montoya testigo de su tiempo. Memoriales
}

\author{
Montoya witness of this time. \\ Memorials
}

María Isabel Artigas ${ }^{*}$

Resumen: Como defensor incansable de los indígenas que poblaban el territorio americano, el Padre Antonio Ruiz de Montoya, misionero de la Compañía de Jesús en América del Sur, fue su defensor incansable en contra de las acciones desarrolladas en América por los representantes de las autoridades de la metrópolis. Para reivindicar las injusticias y evitar el colapso del trabajo misionero recurrió al Soberano español para exponer lo que aquí ocurría. Lo hizo a través de los Memoriales, documentos que mantienen la forma usada en aquel tiempo para ser presentado ante el Rey, de tal manera que un asunto de importancia, sea considerado por el Monarca y su Consejo Supremo de Indias. La fuerza de la pluma del Padre Montoya como también la acusación apasionada, seguida por la súplica para encontrar un remedio a la injusta situación vivida en el Guairá conmovió al Rey de España, que ordenó el análisis y estudio de la cuestión mencionada en los memoriales. Del texto del mismo se deduce además de la historia de los hechos que perjudicaron la coexistencia de los guaireños, la propuesta de las acciones a seguir para encontrar una solución a la situación de cautiverio que padecían los habitantes en las posesiones de la corona en el continente americano.

Palabras claves: misioneros, indigenas, Guairá, Rey, cautiverio.

\footnotetext{
* Miembro de la Fundación Yayetopa. Maestria en Historia de Iberoamérica (con Área de concentración en las Misiones Jesuíticas) por la Universidad do Rio do Vale dos Sinos. Sao Leopoldo. R.S. Brasil. Email: mabelartigas@hotmail.com.
} 


\begin{abstract}
As a tireless defensor of the indians that lived in the american soil, Father Antonio Ruiz Montoya, a missionary of the Jesus Company on South America, worked untiringly against the accions developed by the representatives of the metropoli's authorities. To claim against the injustices and avoid the colapse of the mission's work, he appealed to the spanish soberain so as to expose what was happening. The Memorials are the documents that mantein the form used at that time in order to be presented to the king, so that important issues might be considered for him and the Supreme Council of the Indias. The strength of Father Montoya's plume as his passionate delation, followed by his plea to them to find a remedy to the unfairness lived in Guairá touched the King of Spain, who ordered the analysis and study of the matter. From his text can be deduced not only the history of the events that prejudiced the coexistence of the guaireños, but also his proposals of action in order to solve the captivity situation that the indians suffered by the representatives of the Spanish Crown.
\end{abstract}

Keywords: missionaries, indians, Guairá, King, captivity

Recibido: 13 de setiembre de 2016

Evaluado: 2 de noviembre de 2016 


\section{Un misionero ante el Rey}

El Padre Montoya y sus compañeros entendieron muy pronto que la migración de los pueblos desde el Guairá hasta la actual provincia de Misiones no significaba una solución para los indios: el peligro de los paulistas estaba latente. El Virrey de Brasil, Don Diego Luis de Olivera, a pesar de las súplicas de los PP. Simón Mascetta y Justo Mansilla (Van Suerck), no adoptó ninguna medida para resolver la situación. La estrategia era, entonces, recurrir al Rey de España, Felipe IV, con dominio sobre Portugal y las colonias de Brasil. La Congregación Provincial de 1637 designó al Padre Montoya procurador para exponer ante el Rey los acontecimentos que sucedían en el Guairá, Tape e Itatin y reclamar medidas para enfrentarlos.

Montoya permanece cinco años en Madrid. En sus memoriales informa detalladamente a las autoridades reales, principalmente al Conde-duque de Olivares primer Ministro y verdadera autoridad de España- los acontecimentos que se produjeron en territorios platinos. A instancia del ministro se reúne, en 1638, una Junta compuesta por españoles y portugueses, para proponer las medidas a fin de evitar hechos como los denunciados. De inmediato estas determinaciones se convierten en ley, significando un primer triunfo para las gestiones de los jesuitas. Por Cédula Real, se ordena armar a los indios para su defensa; en 1639 ganaban ellos.

Consideramos conveniente adoptar para su presentación, así como está en la Monumenta Peruana, el siguiente orden:

- Título del documento: es lo que aparece a continuación del número de orden, y responde al contenido del texto; encontramos como mas conveniente para su presentación.

- Texto: mencionamos aqui las características del original, lugar donde se encuentra, su estado, las copias que existen, etc.

- Impresión: destacamos el autor, editor, título de la obra, volume y página donde el texto aparece, en la mayoría de los casos; es lo que nos sirvió de base para nuestra transcripción.

- Edición: especificamos las características de la presente edición, mencionando el autor, título, volumen, editorial y página del texto transcripto, con ortografia actualizada, solución de abreviaturas y notas de esclarecimiento de términos antiguos. Para la redacción de las notas consultamos principalmente el dicionário de la lengua española, editora Garnier Hermanos, Madrid, 1891.

- Destinatario: hace referencia a las personas a las cuales los escritos estaban dirigidos, la mayoría de los textos eran destinados al Padre Provincial de la Província Jesuítica del Paraguay, también encontramos documentos destinados al Rey, a los virreyes, algunas cartas a los gobernadores y correspondencias con otros jesuítas, sus colegas.

- Fecha: consta la fecha del documento, en el caso de las cartas al Padre Montoya incluidas en las Cartas Anuas, son mencionadas las fechas de las Cartas Anuas.

- Bibliografia: citamos las bibliografias que contienen los datos identificadores del texto transcripto. Ellas son las de Hugo Storni (1984) Guillermo Furlong, (1964) y Efrain Cardozo (1979).

- Autores: aparecen aqui los autores que los documentos citaron, comentaron o transcribieron parcial o totalmente. 


\section{Memorial al Rey.}

Denuncia los ataques de los portugueses y requiere la libertad de los indios.

Texto: Original en el Archivo General de la Compañíia de Jesús, Roma. ARSI, Paraq. 11 , ff. 133-134v.

\section{Impresión:}

Edición: El texto original de ARSI es publicado con ortografía actualizada y notas explicativas de términos antiguos.

Destinatario: El Rey de España.

Fecha: 1639.

Bibliografia: Storni, Montoya, ${ }^{\circ} 75$ de p. 432; Cardozo I, pág. 244 nº 1 ; Furlong, Montoya, no27 de p.109.

Autores: Leclerc, No1867; Uriarte 3, pág. 374, N4309; Morales 2, pp. 79-81; Pastells 2, pág. 77; Medina VI, Nº 6843; Sommervogell VII, pág. 320.

\section{Texto}

\section{Memorial al Rey}

"Señor.

Antonio Ruiz de Montoya de la Compañía de Jesús, y su Procurador General de la Provincia del Paraguay, dice: Que estando prohibido por cédulas y órdenes Reales, so graves penas, que los Portugueses del Brasil no puedan entrar en la dicha Provincia, por muchos inconvenientes que de ello resultan, y en particular por las invasiones, que hacen, cautivando y llevandose los indios, para venderlos, y servirse de ellos, en los ingenios de azúcar, por serles de más comodidad, que los esclavos, dádose en dichas cédulas libertad a todos los indios, que así se hubiesen llevado, los vecinos de San Pablo (lugar de señorío del dicho Brasil) y de San Vicente, y otros confinantes con la dicha Provincia: pospuesto el temor de Dios, y en contravención de los dichos mandatos Reales, no solamente han continuado y continúan haciendo entradas, cautivando los indios infieles que hallaban en los montes, como antes hacían, pero se han atrevido, de algunos años a esta parte, a entrar con hostilidad, y mano armada (llevando armados consigo muchos indios de dicho Brasil, que llaman Tupis) en las reducciones de los indios cristianos del dicho Paraguay (que por medio de la Doctrina Evangélica en muchos años, y con inmensos trabajos de los religiosos, y en particular de los de la Compañía se habían poblado) llevándose los pueblos enteros: a que este suplicante, con muy pocos compañeros, los habían agregado, de treinta años a esta parte, que entraron a reducirlos, a nuestra santa Fe, recibiéndola con mucho afecto, y haciéndose cada día muchos progresos en la virtud, aprendiendo oficios, para vivir en comunidad, dándose a la música e instrumentos musicales, con que se celebraban las misas con mucho culto y decencia en ese tiempo formaron trece poblaciones de más de mil y de dos mil vecinos, que pasados los diez años de su reducción, vinieran a pagar a V.M. el tributo, según su Real mandato. Y que el principal autor de estos daños ha sido, y es, Antonio Raposo de Tavares, vecino de la villa de San Pablo, que usurpando el título de Capitán, con ejército formado, entró por las dichas reducciones en forma de guerra, matando indios, sin perdonar las mujeres, ni los niños, con fin de hacerse formidable de aquella desnuda 
gente, para que fácilmente se le entregasen, y poderlos llevar a ceder sus tierras, quemando y profanando los templos, arrastrando las vestiduras sacerdotales, derramando los santos Oleos y haciendo otras mil atrocidades, publicando contras los Sacerdotes de la Compañía, que eran foragidos, y que, por no caber en el mundo, se iban a las tierras, y que era falsa la doctrina que enseñaban, y la suya, de ellos, buena, convidndoles a que pudiesen tener las mujeres, que quisiesen, con otras muchas abominaciones. Con los cuales medios y violencia destruyó las once reducciones, que eran muy lucidas, desterrando de ellas el Santísimo Sacramento, llevando a sus moradores cautivos, y a sus caudillos aherrojados, con colleras, y cadenas, quedando solamente las otras dos reducciones, que se pudieron en este tiempo mudar a parte segura. Con lo cual quedaron asoladas tres Provincias de indios y tres ciudades de españoles, que eran Xerez, Ciudad Real y Villa Rica, debelándolas hostilmente, llevándose consigo parte de los españoles y un clérigo, que actualmente era Cura.

Y habiéndose hecho información de los dichos excesos y enviado los Padres de la Compañía de Jesús de aquella Provincia, uno de ellos a representarlo a V.M. para que mandase poner el remedio conveniente que con santo celo, indignado de ello, mandó se hiciese junta particular, que hasta ahora no ha tenido efecto, y con la dilación, el dicho Antonio Raposo [Tavares] ha continuado sus excesos, con nuevo atrevimiento: pues por Setiembre de 1636, alzando bandera y voz de Capitán, salió de la dicha villa de San Pablo con 150 arcabuceros y 1500 indios de su facción y entró por la jurisdicción del Puerto de Buenos Aires (que es la demarcación de Castilla) y con mano armada y al son de cajas y orden de guerra, llegó a la reducción de Jesús María, el día de San Francisco Javier, con ánimo de coger la gente descuidada, con la celebración de aquel día, que con el aviso que tuvieron se habían recogido en una empalizada, cerrando dentro la Iglesia, que la comenzaron a cañonear, ultrajando de palabra a los religiosos, diciendo: matemos estos perros Jesuítas, y así hirieron tres, de cuatro que había y habiendo tirado más de cuatraocientos arcabuzazos, a uno que hacía mucha defensa (como lo observaron los dichos agresores) solamente le hirieron en un brazo y habiendo durado la pelea cosa de seis horas, defendiéndose los indios con flechas y dos hermanos con sus escopetas, estando las mujeres y niños en la Iglesia rezando las oraciones, pidiendo a Dios misericordia, procurando los contrarios pegar fuego con flechas, que aunque las iban apagando, vino últimamente a prenderse, lo que obligó a los cercados a abrir la palizada, huyendo del incendio, pensando hallar menos daño en los hombres, pero no les valió, porque acudiendo los contrarios al portillo, iban pasando a cuchillo los que iban saliendo, sin perdonar las mujeres, ni los niños, que muchos de los pechos de sus madres volaron al cielo: prendieron a los religiosos, poniéndoles guardas y de industria al resistero del sol, en medio de los leños encendidos de la Iglesia ya quemada, tratándoles muy afrentosamente y arrancándole sus pobres halajas. Mataron 400 vacas, que tenían para sustento de aquellas poblaciones, despedazaron los ornamentos y derribaron el Altar mayor, en que aquel día se había celebrado misa y le hicieron lugar inmundo a la misma Sacristía y después invadieron la reducción de San Cristóbal en día del Nacimiento de Nuestro Señor (procurando cogerlos en semejantes días, por hallarlos más desapercibidos) y lo mismo hicieron en la reducción de Santa Ana, ejecutando en los pobres indios, crueldades inauditas y convidándoles por otra parte con diabólicos halagos, poniéndoles mujeres delante en presencia de los mismos religiosos y finalmente recogieron de las dichas tres reducciones y de otras partes que estaban para reducirse más de 40 almas en un corral empalizado y habiéndolos contado, los repartieron entre los soldados, según la calidad de cada uno y entre todos echaron derrama, para la parte que había de caber, a un religioso de cierta Orden que iba por 
cura de ellos, le cupieron 500 personas que llevó a su convento y asimismo dieron a un clérigo que iba en su compañía buena cantidad de indios y con el mal tratamiento y enceramiento, enfermó mucha gente y no pudiéndola llevar, les pegaron fuego, en la misma empalizada y casas pajizas que tenían y aunque algunos enfermos procuraban escapar de las llamas, no les daban lugar los indios tupis y así se quemaron vivos que el suplicante ayudó a enterrar, porque se halló en aquella ocasión y viniendo a Río de Janeiro esperando embarcación para España, vió entrar muchos barcos cargados de dichos indios a vender y entre otras mercaderías que recibían eran barriles de pólvora, previniéndose siempre de armas y quitándolas de la defensa de aquella costa, para ir a cautivar los dichos indios, en que han puesto toda su granjería y así salen cada año ha hacer las dichas correrías y no han de parar hasta haber totalmente destruído aquella cristiandad, instigados del demonio y hay aviso que este año ha vuelto otra vez a ejecutar las mismas crueldades y traer más indios cautivos.

De los cuales, dichos excesos, se han seguido y siguen otros muchos y graves daños, en deservicio de Nuestro Señor y de V.M. y destrucción de aquella provincia, el uno (que es el más grave), el descrédito de las cosas de nuesta santa Fe, entre los indios, tiernos en ella, por verse cautivar, juntos en comunidad, en mucho más número y con más facilidad después que los religiosos los redujeron a poblaciones, que cuando andaban divididos por los montes, pues esta última vez se han llevado, en pocos meses, más de cuarenta mil personas, que no lo pudieran hacer, ni el diezmo, en mucho más tiempo, cuando hacían las malocas por los montes, que los indios lo podrán atribuir a estratagema nuestra, y el ver que los dichos vecinos de San Pablo, llamándose cristianos, hagan los dichos insultos e inhumanidades, de que podrán sentir mal del nombre cristianos, teniendo por falsa la enseñanza que les hacen, como los mismos agresores lo dicen y más con las profanaciones y sacrilegios que les han visto cometeré mostrándose en sus acciones unos herejes y otros indios con mucha adversión al cristianismo.

El otro daño, el haberse perdido los tributos que los indios habían de dar a V.M. pasados los 10 años, desde el día de su bautismo, por los tratos de diferentes géneros, que comenzaban a tener, sin que hubiera necesidad de pagarse de las cajas de Buenos Aires y Potosí los gastos que hacen el Obispo y Gobernador del Paraguay como ahora se pagan, pues de las dichas provincias se sacará todo bastantemente.

Y otro daño (que es de ponderar) que como dicho lugar de San Pablo es de señorío y gran parte de él está poblado de los bandidos y malhechores de todo el Brasil y que muchos de ellos son cristianos nuevos, se han hecho indómitos, sin conocer a la divina y humana Majestad, mostrándose sospechosos en la Fé, en su proceder y en la comunicación con los herejes de Holanda y que se puede temer les den entrada y abran el dicho camino para las provincias del Perú con manifiesto peligro de ellas: mayormente después que los dichos rebeldes han hecho pie en el dicho brasil.

El otro, que por el dicho camino que han abierto los de San Pablo, muchos de ellos se han ido a vivir a Tucumán y a la Asunción, lugares del dicho Paraguay, viviendo otros en Lima y en el Potosí y se puede temer lleguen a la dicha villa, porque hay aviso del Gobernador del Paraguay, en que dice, que los vecinos de San Pablo estaban 80 leguas de la nación Chiriguana, con la cual si se confederasen (que lo podrán hacer fácilmente, atrayéndoles con halagos y libertad de conciencias) ser fácil con su intervención el apoderarse los holandeses de aquel reino todo lo cual requiere breve y eficaz remedio y el suplicante, habiéndose caminado más de 1500 leguas, viene a postrarse a los pies de V.M. y a representar los dichos daños y para demostración de lo que tiene referido trae 
un mapa que ha hecho de toda aquella tierra y con éste presenta las informaciones que hizo el dicho Gobernador del Paraguay y otras que se hicieron en Río de Janeiro, en lengua portuguesa, por donde consta la verdad de su relación y de muchas singularidades que agravan los dichos delitos, como fue cortarles los brazos a los indios, para herirles con ellos otras muchas inhumanidades excecrables.

Suplica humildemente a V.M. mande le junten con los demás papeles que están presentados y que la Junta con vista de todo, trate de su remedio, sin que se dilate más, y se tome la resolución más conveniente y porque se han traído cantidad de dichos indios a la ciudad de Lisboa y vendidos, siendo libres, se sirva de mandárseles dé libertad, y que lo mismo se haga con los demás que se han vendido y están en el Río de Janeiro, San Pablo, San Vicente y otras partes.

En cumplimiento de lo que está mandado por cédulas Reales: Que en ello los religiosos, que cuidan de la doctrina de aquellos indios y en particular los de la Compañía y los mismos indios, en cuyo nombre también viene el suplicante, recibirán particular merced."

\section{Memorial al Rey.}

Texto: Original en el Archivo General de la Compañía de Jesús.Roma. ARSI. Paraq. 11, 135-141.

Edicíon: El texto original es publicado con ortografia actualizada y notas explicativas de términos antigos.

Destinatario: El Rey de España.

Fecha: Madrid, 1639 (?).

Bibliografia: Storni, Montoya, nº76 de p.433,; Caradozo 1, pág. 244 n²; Furlong, Montoya, $\mathrm{n}^{\circ} 26$ de p.108.

Autores: Morales 2, 81-82,; Leclerc, No 1350, Sommervogel VII, pág. 320,; Medina VI, $\mathrm{N}^{\mathrm{o}}$ 6844,; Uriarte, $\mathrm{N}^{\mathrm{o}}$ 963,; Streit II, Nº 1672.

Texto

\section{Memorial al Rey}

"Háceme mandado, que así como representé a su Majestad y señores del Real Consejo, en un memorial impreso los agravios enormes que los vecinos de la villa de San Pablo y demás villas de la Costa del Brasil han hecho y al presente hacen a los Indios Cristianos e infieles de las Provincias del Paraguay y Río de la Plata representé también los remedios eficaces a tan encancerada llaga (que si es digno de llorar, que a ojos de su Majestad le quiten sus vasallos, los despedacen y maten, no sé que sufrimiento o paciencia bastará a sufrir el disimulo con que no poco a poco, sino con apresurada prisa le ponen en balanza un Reino como el del Perú, caso que más conviene con todo silencio y brazo armado de la potencia de su Majestad remediarlos, que hablar de él, no sea que abramos con nuestras voces los oídos de los que tan atentamente tienen clavados los ojos en las felices glorias de tan gran Monarca, en que la envidia con rabioso despecho pretende hacer presa. 
Entre los Padres más graves de la Provincia del Paraguay de la Compañía de Jesús, convocados en Congregación General, se trató muy de propósito el buscar remedios a estos males y de los que dieron en aquella Provincia y de los que nos comunicaron Padres muy doctos y celosos de la justicia en la Provincia del Brasil (donde está todo el mal) y otras personas seculares, hemos colegido y sacado los siguientes, dando su aprobación a ellos nuestra experiencia de 30 años y encuentros que con armas hemos tenido por la defensa de aquella tierra de su Majestad y de nuestas ovejas, con intento de impedir el paso y camino que han abierto para Potosí.

Dos géneros de medios se han juzgado por necesarios, unos que salgan al encuentro al daño y los repriman otros que curen y sanen los males ya hechos y libren a los inocentes de la muerte contínua en que viven en un perpetuo cautiverio, siendo libres por todo derecho y nacimiento natural. Los que parecen ser convenientes a reprimir estos daños, son los siguientes:

$1^{\circ}$. El primero, es, que su Majestad se sirva mandar se guarde y ejecute la ley que habla en razón de la libertad de los Indios, en que se declara que ningún Indio, aunque sea infiel, no puede ser cautivo, no forzado a esclavitud, por ningún género, ni modo, ni ser privado del dominio natural que tiene de sus bienes, hijos y mujer, declarando deber ser tenidos por libres en el mismo grado que los demás vasallos de su Majestad. La cual dicha ley se hizo en Lisboa a 10 de Septiembre de 1611 y se promulgó en la Cancillería de aquella ciudad a 13 de Octubre del dicho año, conforme lo disponen las órdenes de aquel Reino, libro 1, título 2, capítulo 8 que ordena, que las leyes de aquel Reino se publiquen por el Canciller mayor de la dicha Cancillería y publicada allí obligue en todo el Reino, como enseña Cabedo 1.part. decif. 184, núm. 8.

Y los señores Reyes antiguos, que reinan ya en el Cielo tuvieron particularísimo cuidado desde los primeros descubrimientos de las Indias, así Occidentales como Orientales, de la plena libertad de los naturales y así el invictísimo Emperador Carlos Quinto y el señor don Felipe Segundo y el señor Rey don Sebastian hicieron particulares leyes en esta razón, que notó el Padre Doctor Hernando Rebello en la cuestión 23 de promisionibus, Senonationibus, sec. 5 y otros. Y el santo Rey Felipe Tercero, año de 1605 en Agosto, siendo Secretario Hernando de Matos, promulgó ley, en que prohíbe el cautiverio de los Indios, aunque sean cautivos en guerra justa, y manda, que a los que así fueren tenidos por esclavos, se les diese plena libertad y esto consta por la Consulta que el Consejo de Portugal hizo por este dicho tiempo y en los años de 1607, 1608, 1609, despachó su Majestad cédulas apretadísimas en razón de la dicha libertad de los Indios y apenas ha habido año en que su Majestad no las haya renovado. Y entrándose en el Oriente tras el Evangelio este pestilente estorbo e infamia del mismo Evangelio, de cautivar Chinos y Japoneses y venderlos, salió su Majestad a la defensa, dándoles plena libertad el año de 1602 y el de 1603 volvió a renovar estos sus Reales mandatos, de suerte, que no está la dificultad de este negocio en descuido de los señores Reyes y Reales Consejos, que santísimamente han ocurrido a estos males, sino en la malicia de los Gobernadores y jueces que ciegos con el interés sustentan el día de hoy esta maldad.

Y así se juzga por conveniente que debe su Majestad agravar las penas en esta razón, las cuales deben ser practicables, como que se entienda haber incurrido en pena de caso mayor y culpa lesa Majestad, inhabilidad para oficio y beneficio, así esclesiástico, como secular de suerte que cualquier persona de cualquier estado y condición que sea, que fuere al Sertón y cautivare, vendiere, comprare, diere, presentare, cambiare, trajere o tuviere en cualquier manera que sea Indios o Indias, muchachos o muchachas de las 
dichas Provincias del Paraguay o Chiriguanas que pertenecen al Potosí (de cuyos confines y términos han ya cautivado) o de la Provincia del Río de la Plata, Biaza, Tape, Laguna de los Patos o de la jurisdicción y distrito del Brasil y de sus términos y confines, no pueda ser electo para oficio, ni beneficio alguno de la república, ni pueda ser consultado para él, ni digno de merced alguna, antes sea tenido por extraño de estos Reinos, sin que le valga alegar posesión o prescripción, compra o sentencia como lo declara la dicha ley y enseña el derecho que decide que no hay prescripción contra la libertad: leg. última. Cod. longi temporis prescritio. Que pro libertate leg. usucapionem, ff. de usucapione, Sed aliquando, instit. codem. título, ! lege 6, n£m. 29, part. 3, \& docet Molina tom. 2, de institia tractat. 2, disputat. 79, column. 471, liber homo. Por ser contra el derecho natural, \& habetut C. flagitia 32 q. 7.

Para lo cual ayudar mucho mandar, que los que vinieren a pretender oficios y mercedes o hubieren de ser elegidos para algún oficio de la República, traiga información de como no es de los comprendidos en estos delitos y el que fuere electo, consultado o admitido al dicho oficio, beneficio o merced, sin la dicha información, se entienda ser la dicha elección nula y de ningún valor, ni efecto la merced que se le hubiere hecho y sea privado luego de ella, ipso facto que fuere denunciado y el denunciador tenga derecho a pretenderla, teniendo las partes necesarias, demás de que el tal sea castigado con graves penas, como transgresor de los Reales mandatos. Y las dichas informaciones de abono se hagan de oficio y con citación del Fiscal de su Majestad y cerradas y selladas se envien a esta Corte. Y para que se dé principio a esto, convendra que su Majestad haga justa demostración castigando los delicuentes y los caudillos principales con mayor demostración y rigor y a los jueces a quien se ha cometido el remedio y han disimulado por sus intereses y parte que han tenido en los cautiverios de los dichos Indios, desterrando perpetuamente a algunos de la villa de San Pablo, para que el rigor del castigo ponga escarmiento.

$2^{\circ}$. El segundo medio es, que su Majestad se sirva de mandar, se pida a su Santidad, por medio de su Embajador, confirme las Bulas que en esta razón tienen despachadas sus antecesores Paulo III y Clemente Octavo, en las cuales se declara, no poder ser cautivos los Indios, ni privados de sus bienes, mujeres e hijos, aunque sean infieles, so graves penas contenidas en las dichas Bulas, reservada la absolución a la Santa Sede Apostólica, como lo repara Manuel Rodríguez en sus cuestiones regulares, tom.2 quest. 99, art. 4 en donde de paso se note lo que notó este autor: Cirea quam concessionem nibil venit notandum, sed plorandum cum oculis nostris tot mellia Indorum devastata, corumque terras propijs dominus privatas cernamus,\& Equod plus adlacbrimas compellit est, quod becsacta sant a Christianish Regnum Christi publicantibus contra voluntatem Pape, \& Regun Hipaniarum, las cuales Bulas trae doctísimamente el Doctor don Juan de Solórzano en el tomo que hizo de Indiarum jure lib 2.c.8. n§ 79. \& lib.3.c.7. $\mathrm{n} \S 55$.vers. Quod vt melius, remitiendo Su Majestad la ejecución a la persona que fuere servido para que tenga este punto su efecto.

$3^{\circ}$. El tercero es, que su Majestad mande se declare ser caso de Inquisición el que tratamos y como tal conozca de aquel santo Tribunal, enviando o nombrando desde luego en aquellas partes persona de toda satisfacción, celosa del servicio de Dios y de su Majestad, que proceda contra culpados (con cuya aprobación pasen las informaciones de pretensiones que vinieren a esta Corte, de que se hizo mención en el primer remedio) que para declararlo por caso de Inquisición hay razones muy claras y evidentes y constan de las informaciones que hemos presentado, como son. Desacreditar la Fe entre los fieles, o infieles. Estorbar la predicación del Santo Evangelio, diciendo mal de los 
Predicadores y Religiosos que lo predican. Persuadir a los Indios que no los crean. Tratarlos mal con palabras y con manos violentas, hiriéndolos, dándoles de mojicones y empellones, prendiéndolos en casas particulares, poniéndoles guardas, sin permitirles entrar en sus Colegios, despojándolos de sus halajas, Breviarios, libros y demás cosas, quemar las Iglesias, los Altares y las imágenes, haciendo pedazos otras, romper y despedazar las Pilas del Bautismo, arrojar por el suelo los santos Oleos, arrastrar los ornamentos, llevándolos en despojo. Saquear las Iglesias. Cautivar la gente que a ellas se había acogido, cautivar los Sacristanes y Cantores que servían a la Iglesia: haciendo de estos asaltos y robos de propósito en días de Fiestas más principales, como el Corpus, Natividad y otros muy celebres, metiendo en colleras, y cadenas los presos, llevándolos a vender, siendo Cristianos. Hacer adorar un Idolo que tenían los Gentiles, colocándolo en lugar público, para con este medio y a voz del demonio, que por él hablaba juntar gente ( de que nosotros quemamos cuatro, que eran cuerpos de Indios que habían sido en vida famosos en el trato con el demonio). Obligar a que se casen dos veces a los Indios Cristianos, sabiendo viven sus consortes, obligándolos a ello con amenazas. Apartando los casados, deshaciendo los matrimonios, contra el derecho divino. Hacer lugar de inmundicias los Altares, Sacristías e Iglesias, en que aquel mismo dia se había celebrado el sacrosanto misterio del Altar, y esto en presencia de casi innumerables Indios Cristianos e infieles, desterrando este divino sacramento de sus Iglesias y casas.

Decir que no han menester obras para salvarse, sino que les basta ser bautizados. Que aunque le pese a Dios se han de salvar. Que si les quitan el cautivar Indios e ir al Sertón, han de renegar del ser de Cristianos y de los Oleos que habían recibido. Haber dicho uno de ellos, que en materia de linaje no tenía igual en la tierra y que en el cielo se podía poner barba a barba con el Padre Eterno.

No consentir que los Religiosos prediquen, ni bauticen a los infieles, aunque esten para morir. No consentir que entren a sus tierras a Predicar, saliéndoles al camino y robandoles lo que llevaban, consintiendo que entren otros cualquiera a cautivarlos y traerlos para vender.

Hacer banquetes generales de carnes en el tiempo de Cuaresma y semana santa, comiendo gallinas, patos, puercos, poniendo nombre de Taburon a la ternera y de Dorado al pavo y de sardina a la perdiz y pollos, y contraponiendo su secta a la Predicación Evangélica. Ofrecer a los Indios (que hemos criado con pureza y castidad) Indias para que se amanceben con ellas, incitándolos a que vean su hermosura, dándoles a escoger entre muchas.

Poner nombres del testamento viejo a los Indios, como Adán, Eva, Abacú, Daniel y otros.

Hacer suertes y sortilegios con Misas para saber si les conviene ir al Sertón o si les suceder bien, interviniendo en ello Clérigos y Religiosos, los cuales además de irles acompañando en sus malocas, les van diciendo Misas por los caminos, no teniendo licencia para ello y con infinitos pecados mortales, pues van a su cuenta los suyos y los comunes de todos.

Y uno de los que últimamente fueron estaba excomulgado, por haber dejado sin licencia el Curato que tenía en la Villa Rica y haber sido llamado con censuras de su Prelado y todos los dichos Clérigos y Religiosos ser irregulares, por ser cooperadores y cómplices de estos delitos, muertes y crueldades, entrando en la partición de los robos y de los 
Indios cautivos y los venden, compran y enajenan sin ningún escrúpulo, teniéndolo por granjería y lo peor es que en el fuero interior y exterior, tienen, publican y enseñan que estas maldades no son materia de confesión, aconsejando que no se confiesen de ellas.

Por lo cual muchas personas temerosas de Dios han dicho y lo testifican con juramento (como consta de los papeles que hemos presentado) que se temen hay en aquella tierra, doctrina oculta contra la Fe de Cisma o herejía y confirma esto lo que la voz constante pública, que en el Río de Janeiro hay muchos Indios judaizantes y esto que hemos dicho sólo pertenece al punto que se trata de estas entradas y robos de Indios.

Que en otras materias muy graves que pertenecen al Santo Tribunal hay mucho en que poner la mano. A cuya causa no quieren recibir Comisarios del Santo Tribunal, como es notorio.

Y así conviene que este nuestro caso se le adjudique y conozca de él.

Este medio tenemos por tanto más eficaz, cuanto menos depende de los Gobernadores y justicias seculares, las cuales comunmente por sus intereses propios y de sus deudos, amigos y paniaguados, atropellan con las leyes de su Majestad y ayudan a chupar la sangre del libre e inocente Indio, como uno secular que dejamos en el Río de Janeiro, que hace muy poco fue enviado a la villa de San Pablo a hacer averiguación de estos males que proponemos y preguntando al delicuente que piezas traía respondía: que 200, pues señor con cincuenta cruzados de penitencia que v.m. me dé, ego te absuelvo. Y esto lo vimos publicar por un santo y recto juez. Pero convendr que su Majestad y Real Consejo mande con determinación a los Gobernadores y justicias, asistan y den todo favor al dicho Comisario, poniéndolos muy graves penas, como son de privación de oficio y otras, si no lo hicieren.

$4^{\circ}$. El cuarto medio es, que el Gobernador de Río de Janeiro tenga jurisdicción sobre las villas del Sur, San Pablo, San Vicente y las demás de toda aquella costa, al modo y de la manera que el Gobernador General de todo el Estado la tiene sobre todo el Brasil, porque como el dicho Gobernador de Río de Janeiro tiene allí 600 soldados de presidio, pueda así por su persona acudir al remedio y ejecución de dicha ley, como ayudando al Obispo y Comisario que su Majestad enviare, lo cual no puede hacer por no extenderse su jurisdicción a aquellas partes del sur y aún en donde es Gobernador, no puede ejecutar sentencia alguna, conforme las leyes de aquel Reino, sino que se remite al dicho Gobernador General su ejecución y esto es causa que muchos delitos se queden sin castigo, como vimos por nuestros ojos, que en seis meses que allí estuvimos mataron 23 hombres a arcabuzazos y otras muertes y uno en nuestra presencia en la misma Iglesia de la Compañía de Jesús el día de San FranciscoJavier, estando cantando con celebridad la Misa y preso el delicuente y confesada públicamente la culpa, se quedó sin pena y ya para salir de la cárcel, por falta de potestad en el Gobernador. Y así convendrá que el dicho Gobernador tenga plena jurisdicción en todas las dichas villas.

$5^{\circ}$. El quinto medio es, que Su Majestad mande que la administración del Río de Janeiro sea Obispado, enviando persona celosa y de toda satisfacción, porque como del Prelado que hoy es, hay recurso a la Bahía y apelaciones al Obispo que interponen a cualquier mandato del Prelado, se baraja el remedio y padece la justicia en muchas cosas el cual Obispo que se nombrare, como pastor y Padre de todas aquellas almas, velar sobre los medios que juzgare conducir a este fin que se pretende y dar su ayuda a los demás Tribunales y jueces y es necesario que tenga poder de Nuncio Apostólico para que pueda reprimir los Religiosos que causan estos males. 
$6^{\circ}$. El sexto que así el Obispo, como el Comisario del Santo Oficio y Gobernador de Rio de Janeiro, cada uno por su parte y según lo que le toca, con penas pecuniarias, pérdida de navíos, barcas y demás embarcaciones y lo que en ellas trajeren y otras penas, prohíban a los barqueros y pasajeros de ir al Sertón a Los Patos y demás puertos cuales quiera que sean a traer Indios, con cualquier pretexto que sea, aunque aleguen que los mismos Indios los llaman a que vayan a rescatar Indios, por herramientas que han menester, que estos rescates han introducido, que el que más fuerza tiene venda al flaco y que no se puede defender maldad digna de castigo.

$7^{\circ}$. El septimo, que Su Majestad mande, que ni el Santo Oficio, ni otros Tribunales destierren al Brasil o Río de Janeiro judío ni delincuente alguno, que comunmente los destierran a aquellas partes, de que se ha poblado la villa de San Pablo, que era de 400 hombres y hoy es de 1.500 y de ellos de 30 años a esta parte hemos visto pasar al Perú mucho número de ellos y algunos en hábito de Religiosos, los cuales han alterado los nimos en aquellas partes, poniendo en riesgo las Indias Occidentales, y con porfía han deseado quitarlas a la Corona de Castilla y darlas al rebelde Holandés.

Estos son los medios que parece conducen a atajar con eficacia los daños que se desean remediar. Los que pertenecen al remedio de lo ya hecho son los siguientes:

$1^{\circ}$.- El primero, que se dé libertad a todos los dichos Indios varones, mujeres, niños, muchachos y muchachas, juntando padres a hijos, maridos a mujeres, enviándolos a sus naturales. (Así lo mandó el Santo Rey Felipe Tercero que está en gloria el año de [1]608 al Virrey de la India, que investigase que Indios había esclavos y que los pusiese en plena libertad y que los vistiese a costa de los que los habían cuativado o traído y los volviese libres a sus tierras. Y que lo mismo hiciesen los Gobernadores en sus partidos) este daño notó muy de cerca el Licenciado Andrés de León en su memorial que imprimió para Su Majestad, de la visita que hizo en el puerto de Buenos Aires, fol. 12, n£m.27 y dice así: "Más no puedo dejar de alzar la voz contra la inhumanidad que usan los vecinos de San Pablo en los Indios que arrastran de sus reducciones de estos distritos para esclavitud pesada en sus labores." Y porque enviarlos por tierra desde el Brasil, es imposible casi, por la longitud del camino, por donde es fuerza padezcan otros tantos trabajos como pasaron viniendo cautivos, que su Majestad mande que a costa de los culpados se lleven por el puerto de Buenos Aires en las embarcaciones que se hallaren en Río de Janeiro, que es viaje de 15 a 20 días y aveces no es más de diez o doce que puestos allí, ofrece el Padre Provincial de aquella Provincia, el Padre Diego de Boroa de vender los cálices y ornamentos de su Provincia para ponerlos en sus pueblos y lugares de donde fueron sacados y yo en nombres de la Provincia lo ofrezco.

Y en este punto se debe advertir. Que no se admitan escusas, no digo de los poseedores, sino de los mismos Indios, los cuales amenazados y engañados por todas las vías, dirán que estan libres y que en sus tierras eran esclavos y otras cosas de este género y aunque digan que renuncian a su libertad, porque esta libertad no mira tanto a los particulares como al bien común y crédito de la $\mathrm{Fe}$ y del Santo Evangelio, para quitar el impedimento que en su promulgación se ha puesto en estos cautiverios y porque los infieles que han quedado en sus tierras vean que lo hecho fue por ser los agresores malos Cristianos y que han sido castigados por orden y mandato de su Majestad y restituídos a su libertad y tierras los cuativos. Quia pactis privatorum ius commune laedi non potest, st de pactis. y por esta causa, non potest, non potest quis recusare libertarem sibi ablaram: leg. sinal. Cod. de testament. manumiss. Como, nique proprio consensu se redigere in servitutem. Leg. liberos,Cod. de libert, caus, por ser la libertad cosa pública, y no privada; leg. si quis rogatus 53. st. de fideicominis. libert. y lo enseáa el Doctor 
Barboza tom.2, leg.alia, cap. eleganter, ff. de soluto matrimonio. Y es necesaria esta advertencia por lo que sucedió estando en el Rio de Janeiro, que haciendo cierto exhortatorio a un juez, para que pusiese en libertad a un niño de estos cautivos y tenía su padre vivo en su tierra, le atemorizaron de suerte que dijo estaba muy contento y que no quería ir a su padre, ni a su patria.

$2^{\circ}$.- El segundo medio es, que el Comisario del Santo Oficio, a quien se cometiere este negocio, habiendo publicado y declarado al pueblo la gravedad del delito y como el Santo Tribunal conoce de él, señale t,rmino competente para que todos los que tuviesen Indios contra el tenor de la ley que dijimos, los exhiba dentro del término so pena de excomunión mayor ipso facto incurrenda: la cual comprenda a los que lo supieren y no denunciaren y otras penas que juzgare. Y los que fueren entregando, se vayan enviando a sus naturales, al modo que se ha dicho.

$3^{\text {o. }}$. El tercero es, que Su Majestad mande sean multados y castigados los Gobernadores y demas justicias de aquellas partes que se hallaren haber sido culpados en este delito, o por descuido, omisión o neglicencia, o simulación, habiendo tenido orden de Su Majestad para hacer informaciфn y devasa todos los años sobre el cautiverio de los Indios, como en sus Regimientos se les encarga y no ha habido ninguno hasta ahora que haya cumplido con esta obligación, sólo Francisco de Acosta Barrios, con gran peligro de su vida hizo las informaciones que hemos presentado, siendo proveedor de la Real hacienda y juez de comisión de este caso.

$4^{\text {o. }}$ - El cuarto medio es, que porque hay en dicho pueblo de San Pablo y otros de aquellas Capitanías y en Río de Janeiro y su jurisdicción muchos Indios cautivos que ya no tienen parientes en sus tierras, ni viven sus Caciques, ni en ellas han quedado pueblos, de su gente ha quedado a quien poderse agregar, porque toda la han traído, consumido y acabado los vecinos de aquellas Capitanías, que con ellos se cumpla lo que su Majestad manda en dicha ley. Que se pongan en las reducciones y pueblos o aldeas que ya estan formadas en dichas partes, para que allí vivan con los demás en doctrina y policía, y con libertad de hombres libres, de donde podrán acudir a servir a quien se lo pagaré, sin que se permita que los Gobernadores, no otras personas, ni justicias se sirvan de ellos sin pagarles justamente su trabajo.

$5^{\circ}$.- El quinto y último, y del que depende la ejecución y cumplimiento y buen asiento de todo lo dicho y de cerrar el paso al Perú (que es muy llano) es, que de acá se cambie persona de toda satisfacción, celosa del servicio de Dios y de su Majestad, grave, y que en aquellas partes tenga nombre de recto y de grande autoridad y si tuviere alguna práctica de aquella tierra ser mejor. El cual no sólo lleve papeles, cédulas y comisiones (que de estas son infinitas las que se hallan en los archivos) sino también lleve fuerza y mano, en la forma que los señores del Real Consejo juzgaren y sino lleva esta mano y es de estas condiciones, juzgo que no conviene intentar los remedios, porque entiendo se empeorará el negocio y si la lleva, ser fácil el remedio de los males dichos y de otros de muy grave importancia que los tiempos nos van descubriendo.

Y como de los papeles que hemos presentado consta, que en algunos lugares reciben las cédulas de su Majestad al son de campanas, a que se juntan todo el pueblo con sus armas, mosquetes y mechas encendidas y va el Secretario leyendo la cédula y el Cabildo pregunta al pueblo: Que les parece a Vs. mercedes de esto y si no les conviene, dicen que el pueblo no puede cumplirlo, se entiende harán lo mismo ahora. Y a tal persona que fuere al modo dicho, podrá ayudar al Comisario del santo Oficio y al Obispo y defenderlos del rigor del pueblo. Que aunque los más son pequeños, San Pablo se dice 
comunmente tendrá mil quinientos soldados hechos y muy bien ejercitados y nosotros hemos visto en campo más de seiscientos soldados armados y con muy lucidas armas, curtidos a la descalzes, lluvias, necesidades y trabajos llevando consigo cinco y seis mil tupis y entretenerse por los montes y campos en estas presas, dos, cuatro, ocho y diez años: y tal vez ha sucedido hallar ya a sus mujeres casadas y con hijos y ellos llevar los que engendraron por los montes ya hechos mochileros.

Con esto se consiguen dos cosas. La una, el descargo de la conciencia de su Majestad, librando tanta gente libre de un imcomportable cautiverio, volviéndolos a sus tierras. La otra, que con esto se asegura la Monarquía del Perú, que con tanto conato procuran enemigos de Cristo entregarla a los rebeldes y por ser tierra contigua al Brasil y al Perú y haber camino abierto, es muy fácil entrar derechamente a la villa Imperial de Potosí, de cuyos confines han sacado ya los vecinos de San Pablo, Indios cautivos, y del cual camino diremos, como testigo de vista y haremos clara demostración.

Esto es lo que juzgamos en el Señor y nos parece conduce a lo que se nos ha preguntado y porque para tratar la verdad en materia tan importante, ha sido necesario, que así en nuestro primer memorial impreso, como en este, digamos de algunas personas cosas graves, decimos y protestamos, que nuestro intento no ha sido, ni es que se proceda a muerte, ni efusión de sangre, sino sinceramente decir la verdad y así lo protestamos, pedimos y suplicamos a todas las personas y justicias a quien tocare la ejecución de lo que su Majestad y su Real Consejo de Indias mandare."

\section{Antonio Ruiz de Montoya}

\section{Resumen del Memorial anterior}

Texto: Original em el Archivo General de la Compañía de Jesús, Roma, ARSI, Paraq. 11, pp.143-144.

Edición: El texto original de ARSI es publicado con ortografia actualizada y notas.

Impressão:

Destinatário: O Rei da Espanha, Felipe IV.

Data: Madrid, 1639 (?).

Bibliografia: Storni, Montoya, no77 de p.433,; Furlong, Montoya, p.109.

Autores: Furlong, Montoya, pp. 61-63; Jarque 3, pp.350-353.

Texto

Memorial al Rey

"Señor.

Los remedios que pueden ocurrir a los males que el Padre Antonio Ruiz de Montoya de la Compañía de Jesús propuso en su Memorial impreso, contra los vecinos de San Pablo, son los siguientes: 
1. QUE V. Majestad mande se guarde la ley que se hizo en Lisboa a 10 de Setiembre de 1611. La cual manda, que ningún indio pueda ser esclavo, agravando las penas.

2. QUE se pida a Su Santidad confirme las Bulas de Paulo III y Clemente VIII, que dicen, que ningún indio pueda ser esclavo, agravando asimismo las penas.

3. QUE V. Majestad mande, que el cautivar indios sea caso de Inquisición, por las causas que decimos en nuestro memorial largo, y que luego se envíe y nombre Comisario.

4. QUE el Gobernador del Río de Janeiro tenga jurisdicción sobre las villas del Sur, San Pablo, San Vicente, y al modo que el Gobernador general, porque hoy no tiene jurisdicción m s de para remitir las causas a la Bahía, y así perece la justicia.

5. QUE V. Majestad mande, que la administración espiritual que hoy es, sea Obispado, con poderes de Nuncio Apostólico, para que reprima a los Religiosos que causan tan graves males.

6. QUE el Obispo, Comisario, y Gobernador, cada uno por lo que le toca, con graves penas prohíban las embarcaciones que van a cautivar indios.

7. QUE de aquí adelante no se destierren indios, u otros delincuentes al Brasil, que comunmente los destierran allá, y como es tierra contigua con el Perú y hay caminos muy trillados, han pasado muchos, de que de 30 años a esta parte somos testigos. Los cuales con porfía tratan de entregar a quellas Indias a los rebeldes.

8. QUE V. Majestad mande se dé plena libertad a todos los indios, varones y mujeres, que padecen horrible cautiverio, y que se envien por Buenos Aires, que es viaje de 15 a 20 días, a costa de los que los tienen, que puestos allí, ofrezco en nombre de mi Provincia, de ponerlos en sus mismas tierras, aunque se vendan los cálices y ornamentos.

9. QUE el Obispo y Comisario, con excomuniones obliguen a manifestar los indios, y que esta excomunión obligue a los que no denunciaren de otros, no denunciando ellos.

10. QUE sean castigados todos los culpados, y las justicias que han consentido estas maldades, porque con esto se desagravie el Santo Evangelio, que ha sido infamado entre los gentiles y cristianos recién convertidos.

11. QUE los indios que se hallaren no tener en sus tierras pueblos, deudos, ni a quien allegarse, se pongan en las aldeas de indios que estan en el Río de Janeiro.

12. El último, y de que depende el buen asiento de todo es, que V.M. envíe persona grave, y celosa del servicio de Dios y de V.M. con mano armada de gente, que ayude al Obispo y al Comisario, por que en aquellas villas, parece no conocen a V.M. por sus cédulas, que reciben con mosquetes y mechas encendidas, y nunca las ejecutan.

De todo lo cual se conseguirán dos cosas. La libertad de tantos hombres, que en sus mismas tierras que Dios les dio, los cautivan, venden y compran. La otra, que V.M. asegurar la Monarquía del Perú, que con tanto conato procuran entregarla a los rebeldes, y ya el camino está abierto desde San Pablo a los confines y contornos de Potosí, de donde han llevado ya indios cautivos.

Y protesto que mi intento no es muerte de alguno, ni efusión de sangre." 


\section{Memorial presentado en la Corte de España.}

Solicita que se visiten las Reducciones, sea evaluado su tributo, y enviados los sacerdotes para la conversión de itatines y chiriguanos.

Texto: Copia de un autógrafo de diseño en la Biblioteca Nacional de Rio de Janeiro, Colección De Angelis, I-29-1-91.

Impresión: Cortesâo 1, pp.430-433.

Edición: Edítase el texto que transcribe Jaime Cortesâo con ortografia actualizada y notas.

Destinatario: El Real consejo de Ciudad de España.

Fecha: Madrid, 1639.

Bibliografia: Storni, Montoya, p.433 nº 80; Cardozo 1, pág. 249 n 28;

Furlong, Montoya, p. $107 \mathrm{n}^{\circ} 26$.

Autores: Cortesâo 1, pp.430-433.

Texto

Copia de un memorial presentado por Antonio Ruiz Montoya en la Corte de España en que expone las razones que llevaron a los paulistas a atacar las reducciones y ciudades del Guairá y a él a defenderlas con mano armada.Pide se visenten las reducciones de los indios y se les ponga tributo.

"Señor

Antonio Ruiz de Montoya Procurador en esta corte de la Provincia del Paraguay de la Compañía de Jesús y en nombre y con poder de los indios de las dichas Provincias y de la del Río de la Plata dice que la Compañía de Jesús a costa de inmensos trabajos y de cinco mártires sacerdotes ha conquistado algunas Provincias de infieles de que tiene hoy en las dichas Provincias veinticinco poblaciones de indios, son once que en la Provincia de Guairá le destruyeron y llevaron cautivos los vecinos de San Pablo en la costa del Brasil, destruyendo así mismo tres ciudades de españoles que fueron Ciudad Real, Villa Rica y Xeres. Y de trece reducciones que este suplicante había hecho, solo dos pudo escapar que hicieron número de diez mil almas las cuales el suplicante bajó con inmenso trabajo y costa (y con licencia de la Real Audiencia de las Charcas como consta de los papeles que se han presentado) en setecientas embarcaciones que llaman balsas, al Río de la Plata donde al presente están muy bien sementados y en muy buenos puestos, y con aumentos conocidos.

Y por parte de los autores de los dichos agresores se hizo falsa relación en esta corte diciendo que estos dichos indios los había el suplicante consumido y muerto. Procurando con esto paliar sus delitos tan graves como son haber consumido las dichas once reducciones, vendiendo los indios y matándolos, quemando las iglesias y desterrando de ellas al Santísimo Sacramento y haciendo las abominaciones que constan por informaciones auténticas. Demás de lo cual han cometido otro delito de abrir camino y paso a la villa Imperial de Potosí como también consta [en] las dichas informaciones y cartas del Presidente de los Charcas don Juan de Lizarazu y de los Obispos y gobernadores y avisos que de ello ha dado el Conde de Chinchón Virrey del Perú, lo cual así mismo han pretendido paliar falsamente con descrédito de los 
predicadores evangélicos y del mismo evangelio diciendo que por haber la Compañía de Jesús convertido aquella gentilidad y fundado aquellos pueblos habia abierto el dicho camino, lo cual, se ve claramente ser falso y ajeno de verdad. Porque estando las dichas tres ciudades fundadas por mandato y orden de los Señores Reyes pasados hace cien años y estar derecho de la dicha villa de San Pablo con la villa Imperial de Potosí destruyeron las dichas ciudades a fuerza de armas y juntamente las dichas once reducciones que estaban en contorno de las dichas tres ciudades, además de las cuales destruyeron siete pueblos de indios que estaban encomendados a las dichas ciudades solo con nimo de limpiar el dicho camino para pasar libremente al Perú (como se har demostración muy clara por un mapa que el suplicante trae de toda aquella tierra) y este suplicante les salió al camino para estorbarles el paso con tres mil indios flecheros y por llevar los dichos agresores cien mil tupís, gente bárbara y feroz, e ir tres banderas de escuadra con tres capitanes que hacían al pie de Doscientos mosqueteros no pudo este suplicante impedirles el paso antes le fue fuerza retirarse con muerte de muchos indios y tres padres mal heridos con que los dichos agresores consiguieron su intento de despejar y limpiar aquel camino de españoles e indios para que no hubiese quien diese aviso a la ciudad de la Asunción que sola ha quedado de aquel Gobierno del Paraguay. Y porque constase que aquellas dichas dos poblaciones que el suplicante escapó, estaban conservadas y aumentadas, ofreció los tributos de los dichos pueblos para S. Majestad a Martín de Ledesma Valderrama que entonces era sustituto de Gobernador en la dicha ciudad por don Luis de Cespedes y Xería, que por las dichas causas de destrucción de los dichos pueblos fue llevado perso a la audiencia de los chácarachas y privado del gobierno con otras graves penas que le pusieron, el cual dicho Martín de Ledesma no quiso aceptar los dichos tributos.

Y porque otros pueblos de estos que ha reducido la Compañía han ya cumplido los diez años y por parte de la Compañía se ha requerido a los Gobernadores los visiten y no lo han querido hacer como consta de la visita que don Andrés de León Garavito hizo en el puerto de Buenos Aires (que por ser el número de los indios al pie de quince mil ser considerable el tributo por poco que se les ponga).

A Vuestra Alteza pide y suplica se visiten las dichas reducciones y se tasen los indios que ya hubieren cumplido los diez años para que los oficiales reales cobren y reciban los dichos tributos, señalándoles un moderado tributo conforme a su pobreza y de las cosas que tienen en que lo puedan pagar.

Otro sí, pide que atento a que es de gran servicio de Dios y descargo de la conciencia de V. Alteza la conversicn de los Itatines y Chiriguanas que confinan con Potosí y por la parte del Paraguay tiene ya la Compañía dos reducciones hace ocho años con solos tres sujetos y por falta de ellos no se ha pasado adelante y ser conveniente que antes que los vecinos de San Pablo los ganen y reduzcan (como lo van haciendo) a su devoción, se ganen al servicio de Su Majestad para que aquel paso esté seguro, y, se dé aviso de cualquier suceso al gobernador del Paraguay, como este año pasado lo hicieron los dichos Padres avisando a don Pedro de Lugo y Navarra Gobernador que al presente es en el Paraguay, como pasaba hacia Potosí una compañía de soldados a que acudió el dicho gobernador ayudado de las dichas dos reducciones de cuyo suceso no sabemos aún cosa cierta.

Pide y suplica a V.Alteza mande se le den algunos sujetos para la dicha comquista pues es de tanta importancia al servicio de Dios Nuestro Señor y de V. Alteza y de que depende en gran parte el seguro de aquel paso junto con los demás remedios que en sus memoriales a propuesto, porque el número de diez y ocho Padres que se han concedido 
a aquella Provincia es muy poco por haber muerto en el cultivo de los dichos indios veintiocho sacerdotes por los muchos y grandes trabajos que all padecen."

\section{"JHS}

Padre Provincial, éste es el borrador del memorial que presenté a Su Majestad obligado de las calumnias que nos ponen y de queme avisñ el Señor D Juan Palafox y Sr. D. Juan de Solorzano con el amor que nos tienen que es muy grande y juzgado por muy importante y el Padre Crespo que así se haga, deseo muchísimo que el alguacil mayor que llevó don Andrés de León a ese puerto y tiene cédula de futura sucesión de Tesorero o contador de esa ciudad y quiere ir en mi compañía a esa ciudad se le cometa la visita de nuestras reducciones y tasa de esa gente que como tiene el espíritu de D. Andrés [de León] espero lo hará muy a gusto y la tasa conforme a la pobreza de esos pobres porque si se comete al Gobernador temo mal suceso. Entiendo lo alcanzaré."

\section{Memorial al Rey.}

Informa respecto de los daños producidos por los portugueses y suplica el remedio para evitarlos.

Texto: Copia autógrafa en la Biblioteca Nacional de Rio de Janeiro, Coleção De Angelis, I-29-1-103.

Impressão: Cortesâo MCA 3, pp.295-297.

Edición: Se edita el texto transcripto a través de Hélio Vianna con ortografia actualizada y notas.

Destinatario: El Rey de España, Felipe IV.

Fecha: Madrid 1639.

Bibliografia: Storni, Montoya, pág. 433 nº 81.

Texto

Memorial al Rey

"Señor

El Padre Antonio Ruiz de Montoya, Procurador General de la Compañía de Jesús de las Provincias del Paraguay, Río de la Plata y Tucumán y de las Misiones y Doctrinas de la dicha Compañía tiene de los indios de las dichas provincias, digo: Que constando a V, Majestad de las invasiones que los moradores de la costa del Río de Janeiro y Espíritu Santo y en particular de las Villas de San Paulo han hecho en las dichas provincias a traer cautivos y vender los indios de ellas cometiendo las atrocidades que son notorias y abriendo la puerta a los enemigos holandeses del Brasil a entrar en el Perú, V. Majestad Dios le guarde, mandó hacer Junta sobre este negocio la cual con tan gran celo y aciertos, como de tan buenos ministros se esperó siempre, consultó a V, Majestad lo que convenía hacer de que ando procurando los despachos para llevarlos a las dichas provincias.

Y por cuanto después de esto así en la flota, que ahora llegó del Río de Janeiro como por vía del Perú, ha venido aviso de otra nueva invasión que los dichos delincuentes han 
hecho a continuar la asolación de las dichas reducciones de Indios cristianos y dádoles batalla para esto, en la cual mataron entre los demás a un religioso de la Compañía de los que doctrinan los dichos indios e hirieron otro de tal manera que murió de las heridas y de las dichas invasiones se siguen también las dañosas consecuencias que demás de ser notorias avisa por la carta que de nuevo presentó del Presidente de las Charcas.

Y lo que es más de ponderar y digno de más castigo es que yendo el Corregidor a quien allá llaman Oidor, por nombre Francisco Tabera de Neiva, a la visita que llaman Correción de la dicha villa de San Pablo, adonde está la mayor parte de los dichos indios tan injustamente cautivos y traídos del Paraguay, en lugar de ponerlos en libertad como por su oficio y regimiento era obligado, no sólo los dejó en cautiverio y esclavitud, pero como de tales esclavos venían barcos cargados a vender al Río de Janeiro, fuera de los que también vinieron para la hacienda que tiene, y aun pasaron otros a Lisboa y no digo del dinero que dándoselo al dicho Corregidor los dichos de San Pablo los dejaba con los dichos indios hechos esclavos a que V. Majestad por sus leyes da por libres de todos los cuales excesos y en particular de este tengo informado en la Junta, y era público en aquellas partes y de todos los dichos insultos de unos y de otros y hasta de los eclesiásticos, demás de ser tan notorios estan presentados tantos papeles e informaciones auténticas.

Y ahora se ha dicho que algunos de los dichos delincuentes han pedido perdón al Virrey del Brasil ofreciéndose a venir a servir en la guerra de Pernambuco, los cuales a trueque de pasar dos años en que no vayan a continuar con las dichas entradas que cada día hacen, estarán mejor en la dicha guerra y aún en las cárceles de Lisboa como se ha mandado por V. Majestad que sean traídos.

1. Pido y suplico a V. Majestad que Dios guarde que, atento a lo referido y en particular a lo nuevamente sucedido, que V. Majestad sesirva mandar que caso que se haya dado el dicho perdón que eso no perjudique al derecho de las partes ni terceros como lo es en primer lugar mi dicha Provincia de la Compañía, cuyos religiosos han muerto, herido y gravísimamente maltratado y cuyas iglesias han destruído, robado y profanado con tan enormes sacrilegios, ni tan poco perjudique al darse libertad a los dichos indios, dejándolos en poder de quien tan injustamente los tienen, sino que como V. Majestad ha mandado se me entreguen o a mi o a los religiosos de la Compañía que los pidieren para llevarlos a sus tierras y reducciones y a los casados a sus mujeres e hijos, pues además de esto ser justicia y obligación de conciencia, aún para lo temporal, buen suceso de la dicha guerra del Brasil, es necesario lo que aquí pido, por cuanto es notorio que los indios del dicho Brasil, viéndose en la ciudad de la Praiva maltratados de los portugueses y que las justicias que los debían de amparar antes lo consentían, ayudaron a los holandeses a ganar la dicha plaza y que entre los que V. Majestad manda traer presos, sea el dicho que fue Corregidor que allá llaman Oidor Francisco Taveira de Neiva, asi por ser causa de tantos males e injustos cautiverios dejando como es notorio que dejo a los dichos indios en poder de los que tan atrozmente los cautivaron, trajeron y vendieron, como ya en la Junta cuando se presentaron los papeles yo informé, y con lo cual se animaron los sobre dichos delincuentes a volver ahora de nuevo a cometer los mismos insultos y muertes de religiosos, y así mismo porque mandando V, Majestad ahora que el Gobernador y el Oidor que sucedió al dicho Tabera, en cuanto llega el Obispo acudan a esto prometiéndoles hacer merced si lo hicieren o castigo si en ello faltaren, aún para este particular efecto es necesario hacerse las dichas demostraciones de castigo o a lo menos de ser traídos presos el dicho Tavera que no pidió el dicho 
perdón y los $\mathrm{m}$ s que van nombrados que no le hubieren pedido, fuera de ser justo por tantas razones no dársele o a lo menos cuando no sean castigados que sean traídos fuera de aquella tierra.

Y todo lo que aquí pido es con protestación de que no pretendo pena de muerte, ni mutilación de miembro, ni efusión de sangre, sino solamente mi justicia y de la dicha mi provincia y religiosos, y de los dichos indios y su libertad, a los cuales yo con mis compañeros he reducido y convertido a nuestra santa fe católica y quedo descargado ante Dios Nuestro Señor y ante V. Majestad y sus tan buenos y celosos ministros como lo son los de la dicha Junta con esta diligencia, porque la importancia de la materia es cual se ve y aún mucho más y como avisan no menos que un Presidente de las Charcas y es notoria y que por mucho y muchas demostraciones que en razón de esto se hagan ser poco y recibir, Justicia y Merced."

\section{Memorial al Rey.}

Hace un relato de los daños producidos por los portuueses y pide autorización para que las reducciones puedan tener armas de fuego para la defensa.

Texto: Copia autógrafa em la Biblioteca Nacional de Rio de Janeiro, Coleção De Angelis, I-29-1-104.

Impresión: Cortesâo MCA 1, pp.433-434.

Destinatario: El Rey de España Felipe IV.

Fecha: Madrid, 1640.

Bibliografia: Storni, Montoya, p.434 no 88; Cardozo 1, p.250 no 29; Furlong, Montoya, p. $110 \mathrm{n}^{\circ} 28$.

Autores: Cortesâo MCA 1, pp.433-434; Vianna 4, pp.394-395.

\section{Texto}

Copia de la petición del Padre Antonio Ruiz de Montoya a su Majestad, relatando los estragos de los indios infieles y de los paulistas en las reducciones de la Compañía de Jesús y pidiéndole licencia para que las dichas reducciones puedan tener armas de fuego y así defenderse de las invasiones de los paulistas.

\section{"Señor}

Antonio Ruiz de Montoya de la Compañía de Jesús, Procurador de la Provincia del Paraguay en nombre de dicha provincia y reducciones y con tanto trabajo y gasto de la Real hacienda tiene la Compañía de Jesús, fundadas en dicha provincia dice que las dichas reducciones de algunos años a esta parte han recibido mucho daño y menoscabo por la mucha mortandad que ha habido en ellas así de los indios infieles a quienes estan vecinos como en las invasiones que los vecinos de San Pablo han hecho cautivando muchos indios y matando otros, y algunos religiosos de la dicha compañía por querer ampararlos y defenderlos, lo cual es todo contra la promulgaciфn del Santo evangelio y enseñanza de los ya convertidos, pues resulta el llevarlos cautivos así los dichos indios gentiles, como los vecinos de San Pablo para venderlos en el Brasil para los ingenios de azúcar a cuya causa va todo en gran disminución por estar las dichas reducciones más de cien leguas de la ciudad de Asunción cabeza de la gobernación del Paraguay de 
donde es imposible el tener ningún socorro para su defensa como consta del hecho pues en las invasiones que dichos vecinos de San Pablo [hicieron] no han sido socorridos y ayudados a cuya causa los dichos vecinos de San Pablo han cautivado y llevado por esclavos muchos indios y reducciones enteras, como consta por los recaudos que V.M. se sirvió mandar despachar para la recuperación de dichos pueblos, los cuales es imposible se puedan en adelante guardar y defender sin defensa de armas así de fuego como las demás que usan y ejercen los vasallos de V.M. para defender sus Reales Tierras y vasallos, que de otro modo ser imposible, caso que los vecinos de San Pablo vuelvan a infestar aquellas reducciones.

Por lo cual:

A V.M. pide y suplica se sirva de hacerle merced de mandar dar licencia para que las dichas reducciones tengan las armas de fuego necesarias para defenderse de las dichas invasiones que hacen dichos vecinos de San Pablo tan en daño de los dichos indios y sus reducciones pues si no hay con que defenderlas quedaran todas desiertas como lo estan muchas que eran las mejores que había en aquellas provincias que en ello recibirán merced."

\section{Memorial al Rey.}

Informa sobre la no ejecución de las órdenes reales por causa de las rebeliones de Portugal.

Texto: Original en el Archivo General de la Compañia de Jesús, Roma, ARSI FG 845/85 pp.48-48vta.

Destinatario: El Rey de España, Felipe IV.

Fecha: Madrid 1640 (?).

Bibliografia: Storni, Montoya, pp.434 no 91.

\section{Texto}

\section{Memorial al Rey}

"Antonio Ruiz de Montoya, Procurador General de la Provincia del Paraguay y Procurador General de los indios de las dichas Provincias, dice: Que continuando los servicios de sus antepasados, que hicieron a V.M. en tierra firme, y en el Perú, que por historias públicas consta, ha treinta años que se ocupa en la Provincia del Paraguay, en reducir a la obediencia de la Iglesia, y de V. Majestad, grande suma de indios infieles, de que él, y sus compañeros formaron a costa de inmensos trabajos y de su sangre muchas villas y porque algunas de ellas fueron hostilmente invadidas de los Portugueses de la costa del Brasil, ocurrió con los dichos poderes a los pies de V.M. por el remedio.

Y habiéndosele mandado representase los medios que podían ponerse a semejantes delitos, lo hizo en un memorial impreso: los cuales mandó V.M. se pusiesen en ejecución, de que por el Consejo de Portugal se despacharon cédulas y cartas particulares para los Gobernadores del Brasil, y principalmente para don Jorge Mascareñas, Virrey de dichas Provincias.

Y porque con las nuevas rebeliones y novedades de Portugal (de que todos los vasallos de V.M. esperamos glorioso fin) se ha impedido la ejecuciøn de dichas órdenes, que la 
pedían muy presta, de más de que con justa razón se pueden temer las mismas novedades de portugueses, contra las dichas Provincias del Paraguay y Río de la Plata; así por ser cercanos los unos a los otros, como porque en las dichas Provincias hay muchos portugueses avecindados, ha juzgado por conveniente hacer un mucho servicio a V. Majestad proponiendo algunas cosas importantes para la seguridad de aquellas Provincias, que ya hoy son frontera de enemigos tan declarados, y tan vecinos por allí del Perú, que con facilidad podrán acometerle, así por mar, por el puerto de Buenos Aires, como por tierra por la ciudad de la Asunción, cabeza del Paraguay, y por las reducciones y poblaciones de indios, que quedan referidas, para que rconocidas sus proposiciones, por la junta que V. Majestad se ha servido concederle para solo este fin, proponga a V.M. lo que juzgare ser más de su Real servicio."

\section{Memorial al Rey}

Refiere el procedimiento irregular del Gobernador y refuta las acusaciones de los misioneros.

Texto: I. Archivo General de las Índias, Nº 74-3-31.

II.Trelles, Revista de la Biblioteca pública de Buenos Aires, III, Buenos Aires $1881,215-252$.

Impresión: Hernández, Organización Social 2, pp.620-639.

Edición: Se edita el texto transcripto por P. HERNANDEZ con ortografia actualizada y notas.

Destinatario: El Rey de la España.

Fecha: 1643.

Bibliografia: Storni, Montoya, p.435, №100,; Furlong, Montoya, p.134, №37.

Autores: Hernández 2, pp.620-639; Pastells 2, p.77; Medina 6, № 6845,; Streit 11, No 17, p.23.

Texto

Memorial al Rey

"Señor

1. Antonio Ruiz de Montoya, de la Compañía de Jesús, Procurador de la provincia del Paraguay y Río de la Plata, dice:

Que don Pedro de Lugo, caballero de la orden de Santiago, fue proveído por Gobernador del Paraguay, sólo a fin de que atendiese a reprimir y castigar los portugueses, que hasta hoy infestan aquellas provincias, habiéndose reconocido en él en esta Corte gran virtud, que fue suplemento a los años y experiencia. Porque para tomar aquel gobierno, dejó el manteo y sotana de estudiante. Procedió en su gobierno ajustadamente. El cual, además del orden general sobredicho, recibió orden particular de V.M. para que efectivmente castigase dichos portugueses, en tiempo en que iban entrando por aquellas tierras quinientos, con dos mil indios tupís, a acabar de destruir el residuo de reducciones hechas por los religiosos de la Compañía de Jesús: los cuales, habiéndolos negado el socorro que pidieron al Gobernador de Buenos Aires (a quien 
competía darlo, por ser su jurisdicción), lo pidieron al dicho D. Pedro de Lugo: a que acudió prontamente, saliendocon setenta españoles. Y para ser ayudado de los indios, les prestó siete mosquetes, que entregó al hermano Antonio Bernal, religioso de la Compañía, que, seglar, por su mucho valor, ocupo muy honrosos puestos en la guerra de Chile; el cual salió con los indios, acompañando al mismo Gobernador. Puestos ya a media legua del enemigo, y reconocida su ventaja, no quiso pasar adelante el Gobernador; antes hubo pareceres de retirarse. (Hace mención la carta para S.M. del Cabildo ecco. de la Asunción) Determinóse el hermano Antonio Bernal a acometer al enemigo; matóle un buen número, e hizo presa en diez y siete; los demás desbaratados, se acogieron a los montes, por cuyas espesuras perecieron; y consta de personas que ha poco que vinieron de Brasil a esta Corte que solos trinta volvieron a sus tierras.

2. Los diez y siete cautivos entregaron los indios al Gobernador; el cual, atemorizado por la novedad del suceso que nunca imaginó, por no haberse visto en otro, y temiendo que en venganza volvería todo Portugal a destruir la tierra, reprendió severamente a los indios, condenando en esta acción a los religiosos, que en tan justa defensa habían ayudado; dio libertad a los presos; regalólos y llevólos consigo a su gobierno, en donde se pasearon libres. Requirióse al Gobernador por parte de los indios que los castigase o los remitiese a la Audiencia de los Charcas, que ya prevenida con sus Provisiones Reales, había mandado que con rigor fuesen ejemplarmente castigados semejantes delincuentes. Hízosele notoria una Cédula de V.M. despachada a los Gobernadores de aquellas provincias en que V.M. dice estas palabras: "Me ha parecido ordenaros y mandaros (como lo hago), procuréis por todas las vías posibles haber a las manos y castigar con grandes demostraciones los delicuentes y personas que se ocupan y entienden en las dichas crueldades y otras cualesquiera, con que se perturba la paz y quietud de la república, y por el consiguiente cesa la propagación del Evangelio; haciendo para la mejor ejecución de lo que se desea todas las diligencias que convengan, sin perdonar ninguna, de suerte que se consiga lo que se pretende; sobre que os encargo la conciencia, etc." [Real Cédula de 12 de Setiembre de 1628]. "A quién, Señor, por pusilánime que fuera, nomovieran palabras tan demostrativas del Real y cristianísimo celo de V.M., en ocasión tan nacida a hacer un acto celoso de justicia, o por lo menos de obediencia a tan ajustado precepto? A todo esto cerró los oídos, abriendo los ojos al despojo dedos mil almas que el enemigo había cautivado, para ponerlos en perpetua esclavitud, como hacen a los negros de Angola. Esta presa repartió entre sus soldados, premiando su poco nimo con ella, cargando de denuestos los indios que la ganaron. Cinco de los delincuentes hicieron fuga; y entre ellos uno que dio la muerte con un mosquetazo al P. Diego de Alfaro, de la Compañía, Comisario del Santo Oficio y Superior de aquellas reducciones.

Pretende el Gobernador por disculparse, que se quiten las armas a los indios y las doctrinas a la Compañía.

3. Apretado el Gobernador con los requerimientos dichos, trató de anticipar su defensa con informes e informaciones para V.M. y Real Consejo de Indias, en que según corrió allá voz, reprueba con aparentes razones el manejo de armas de los indios, que poco antes efectivamente había aprobado, entregándoselas en sus manos; sacando por ilación que aquellos alborotos y muertes de portugueses, los han ocasionado los religiosos de la Compañía; y quizá lo confirmar con la destrucción que los portugueses hicieron de tres ciudades, de cuatro que formaban la provincia y gobierno; a cuyas calumnias satisface el venerable Cabildo Sede vacante de la ciudad de la Asunción, en una carta escrita a V.M., de cuyo traslado auténtico, que de allá se remitió, hace presentación el 
suplicante; la cual, cuanto más se libra de pasiones, tanto más acredita sus verdades. Y la acción misma de haber rechazado a los rebeldes portugueses, queda muy calificada con las palabras referidas de la Real Cédula que apoyan el servicio que dichos religiosos hicieron a V.M.

5. Y si la remisión del Gobernador hubiera prevalecido, quedaban los portugueses con más fuerza para proseguir su intento de apoderarse de la ciudad de la Asunción, de donde con suma facilidad se apoderarían de los ríos Paraná y Paraguay; y navegando por ellos, se harían señores de toda la tierra y mar, desde Buenos Aires a Lisboa y Holanda; y trajinarían azúcar y otros frutos de aquella fértil tierra; y con cascabeles , cuentas, alfileres y otras cosillas, ganarían (que lo saben hacer) infinidad de gentiles que habitan aquellas extendidas tierras, con que se harían inexpugnables, e irían abriendo camino fácil al Perú Y si estos lances reconoció el Gobernador, no se debe juzgar por acción fiel a V.M., quitar las armas a los que con tanto valor rechazan al enemigo. Si no lo reconoció, podrá se excusar con la poca experiencia, falta que en los que gobiernan no es pequeña. Las conveniencias de estas armas tienen el suplicante propuesto a V.M., y respondió a sus objeciones en el Consejo Real de Indias, en el de Guerra, en dos Juntas particulares y en el Consejo de Estado; cuya ejecución tiene V.M. remitida al Virrey del Perú.

6. Consultando el Gobernador con los émulos de la Compañía el remedio para que cesen los alborotos de los portugueses, hallan por conveniente se quiten aquellas Doctrinas a los que con su sangre las han fabricado, o que por lo menos se haga estanco de ellas, para que se den a los religiosos de otras órdenes que más baja hicieren en la limosna que V.M. da a los Curas; porque habrá religiosos que sin tanto gasto como V.M. hace con la Compañía, con sola la natural sustentación las servirán (así lo dicen). Cuanto a lo primero, véase lo que el Gobernador hizo, y lo que los indios animados de los religiosos hicieron, y queda referido en el n.1 y 2, donde consta quien fue leal vasallo de V.M., ejecutor de sus Reales mandamientos, y de ahí se sacará si merecen dichos religiosos ser privados de dichas Doctrinas. Cuanto a lo segundo, hicieron mal la cuenta; y así piden mucho m s de lo que V.M. da a la Compañía. Y pruébase así. Da V.M. la limosna para diez reducciones a menos de cuatrocientos pesos corrientes a cada una. Tiene hoy la Compañía, sin las que han destruído los portugueses, veinticinco; y en ellas tiene empleados cincuenta sacerdotes, sin otros religiosos legos de que se ayudan. Repartida esta limosna entre los cincuenta sujetos, cabe a cada uno a menos de sesenta pesos; los cuales, es claro que no bastan a la natural sustentación, pues da V.M. en otras partes y a otros religiosos a setecientos, a mil y a mil y quinientos pesos a cada uno. Además que este dinero se ha empleado en hierro y herramientas, que se dan gratis a los indios para sus labranzas; en anzuelos, cuentas y alfileres para atraer a la fe a los gentiles, y en ornamentos para el culto divino; y para esto se va reservando parte de esta limosna, para que los procuradores que vienen a esta Corte, lleven de acá lo referido más barato, en mayor cantidad y mejor. Así lo ha ejecutado el suplicante, haciendo aquí ornamentos varios, imágenes de bulto y pincel, en buen número, instrumentos m£sicos para las iglesias, órganos, cosa allá nunca vista de aquella gente; con que se espera que a su novedad se convertir $\mathrm{n}$ a nuestra santa fe muchos gentiles, como se ha hecho con la música eclesiástica; y ayudados de limosnas, imprimió en esta Corte tres libros de aquella generalísima lengua, muy importantes para aprenderla, para predicar y para que los indios aprendan la Doctrina cristiana y juntamente el idioma castellano, como tiene mandado V.M.; de que sacó mil y cuatrocientos cuerpos, que ya encuadernados tiene para llevar a su provincia. Y afirma con toda verdad que ni un hilo de ropa ha comprado, ni tiene ya con qué, para el vestuario de los Padres, que es el título con que 
se da y recibe esta limosna. Conténtanse los Padres con vestirse de lienzo de algodón, cosa vil, que con barro y ciertas hojas se tiñe con facilidad, y con la misma se destiñe.

Acusaciones contra los Misioneros: Cargos

Hallá el Gobernador y sus secuaces para apoyo del destierro y privaciones de Doctrinas que desean, graves delitos contra dichos religiosos; de que sin asco han hecho, siendo laicos, cabeza de procesos criminales, con denunciaciones en forma, como consta de los papeles que exhibe el suplicante; y se reducen a nueve: 1 Que tienen oculto un gran de que se aprovechan.- 2 Que ponen mal a los españoles con los indios.- 3 Que no quieren que los Obispos visiten sus Doctrinas.- 4 Que no quieren que los Gobernadores visiten.5 Que tratan y contratan.- 6 Que no quieren que los indios sirvan a los españoles.- 7 Que los indios que ha convertido la Compañía a la Iglesia, ha sido por armas.- 8 Que dan armas de fuego a los indios.- 9 Que despueblan las reducciones de indios sin licencia de V.M. A éstos se reducen los pecados y crímenes de dichos religiosos. Y aunque cada punto pedía respuesta muy lata por haber materia, ser fuerza ceñir este Memorial.

\section{El tesoro}

El primer fingido crimen es que el suplicante, como quien ha penetrado tanto por aquellas tierras, en busca de gentiles, halló un tesoro muy grande de oro, que tiene escondido. Y según el suplicante vio en una carta de un religioso poco afecto a la Compañía, escrita a D. Pedro Esteban Dávila, Gobernador de Buenos Aires, afirma que el suplicante, enviaba de noche a sacarlo con indios muy confidentes, y de secreto; y que por no tener donde poner tanto oro, lo echaba en un aposento, y de este oro se aprovechaba toda la Religión.- A esta antigua calumnia respondió el suplicante en un libro que imprimió en esta Corte, convenciendo la falsedad de invención tan ajena de toda verdad. Y el Gobernador don Pedro Esteban Dávila, habiendo dado aviso con toda aseveración de este tesoro escondido, ya bien desengañado, volvió a escribir a V.M. que había sido falsa invención de los émulos de la Compañía, como consta de su carta, que el suplicante imprimió en su libro. La eficacia de este Gobernador fue tanta en la averiguación de este caso, que enviaba un Alcalde ordinario al desembarcadero a visitar las alhajas y aún los ornamentos de los Padres que iban a su gobierno; molestia que llevaron con sufrimiento, sin saber entonces el fin. "Vio por ventura alguno de los delatores alg£n grano de oro en indio? Cien años ha y más que es habitada aquella tierra; y hasta hoy no se ha visto cosa semejante, y mucho menos es de creer que tienen oro que por una planchela vieja de latón o de cobre trocarían un hijo; porque estiman ponerse por ornato en el pecho alguna cosa de estas. Otras muchas razones se dejan que convencen. Pero si ya no basta la simple afirmación, dice el suplicante que por la reverencia que debe al venerabilísimo Sacramento del Altar, que como sacerdote (aunque indigno) ofrece da día, jura con toda la solemnidad necesaria, que es invenciфn de gente de depravada intención. Dieron por testigo de esto a Pedro de Alvarado Bracamonte que perdido por aquellos campos, dio en unas reducciones de la Compañía, el cual en una declaración jurídica que el suplicante presentó, declara haber sido falsa imposición ésta y otra que le ahijaron; declara el buen tratamiento que le hicieron los Padres y los indios (porque corrió voz que le habían muerto), declara la cristiandad de los indios, la limpieza, ornato y música de las iglesias; declara cuán lejos están los Padres de servirse de los indios, declara que no se les vió escopetas (porque aún no las había prestado D. Pedro de Lugo); declara otras cosas imputadas de émulos, a que se remite el suplicante.

\section{Poner mal los españoles con los indios}


La segunda calumnia es que los religiosos ponen mal a los españoles con los indios; y traen en prueba la guerra que hay viva en la provincia del Calchaquí, haciéndolos causadores de ella. Y pudieran traer la historia de los indios Guaycurús, que han sido inconquistables; de quienes hace mención la carta de la Sede vacante del Paraguay, punto muy reparable. La historia de Calchaquí conviene explicarla, porque ha muchos años que se empezó, y muchos de los émulos, por ser entonces de poca edad, no saben la historia, que pasó así. La provincia de Calchaquí fue inconquistable, por las tierras tan agrias, que para su habitación escogió aquel gentío. Acudían a los valles cuando y como querían a servir a los españoles, llevados de algún interés, como lo hacen cuando se les antoja los Guaycurús en el Paraguay. Entró por estas montañas el apostólico varón Padre Juan Darío con un compañero, que fueron los primeros que echaron la hoz a aquella mies, reduciéndola a poblaciones. De toda aquella gente fabricaron cinco. Aprendieron con incansable porfía su lengua, en que les predicaron, enseñaron y bautizaron. Del trabajo e inusitadas comidas y crecidas edad, estuvo este fervoroso varón para rendir la vida. Acudieron luego los españoles por el servicio personal. (Juzgan, Señor, algunos, que en recibiendo el gentil el agua del bautismo, es ya oveja que se ha de dejar desollar aunque le pese, y que el cura ha de cerrar los ojos; y si reprende o habla, él saldrá mordido). Persuadieron los PP. a los indios que acudiesen al servicio de los españoles. Ibaseles cada día aumentando el detestable servicio personal (no se disputa aquí si se debía), con ausencias largas de sus mujeres e hijos, y pérdida de sus labranzas. Los españoles frecuentaban los pueblos, a título de que cualquier desmán de los indios había de cargar sobre los pobres Curas. Tratarles de que hay Cédulas de los señores Reyes, y Ordenanzas cofirmadas de D. Francisco de Toledo, que prohíben estas entradas, era sacrilegio y crimen para tratar de la expulsión de los Curas. Creció la libertad hasta la impudicia contra las mujeres e hijas de los indios, que ya atosigados, zaherían a los PP. que por su causa tenían tan pesado yugo, y que el de Dios era insufrible; pues gentiles, vivieron con desahogo y libertad; y ya cristianos, experimentaban una intolerable servidumbre. Por otra parte los españoles, mostrándose ofendidos, se quejaban de los Padres, diciendo que se alzaban con sus indios; y asi trataron de que los religiosos dejasen aquellos pueblos. Así se ejecutó con harto sentimiento de los indios, que declararon bien sus lágrimas y llantos. Los españoles, juzgando por de ovejas aquel rebaño, ya sin pastor subieron a la sierra. Halláronlos tan fieros tigres, que algunos quedaron muertos a sus manos, y otros escaparon apenas con las vidas. Encarnizados los indios, bajaron a los valles, asolaron con rabiosa furia la ciudad de Londres; mataron los españoles, los negros, los indios, las mujeres y niños que pudieron haber a las manos, sin perdonar a cosa viviente. Ni perdonaron las viñas; abrasaron las mieses, robaron cuantiosos números de hacienda de las casas, ropa de los obrajes, sin dejar en las estancias cabeza de ganado. Salieron desvergonzadamente ufanos con los afortunados sucesos a campo con los españoles varias veces, saliendo vencedores; impidieron el paso del Puerto de Buenos Aires al Perú, con que causaron muchos daños. Proveyó de socorro la Audiencia de los Charcas con soldados, y sesenta y dos mil pesos corrientes de la Real Hacienda de V.M. y por cabo a D. Antonio de Ulloa, que a la sazón hacía oficio de Fiscal. El cual, aunque hizo su esfuerzo para alcanzar el remedio, no consiguió nada. El escarmiento hace que los españoles deseen con insistencia que estos indios se recojan de paz, y vivan y gocen de ella a su antiguo modo. El Presidente D. Juan de Lizarazu, buscando medios para esta pacificación, le parece único que la Compañía vuelva a recoger de nuevo esta gente, y así lo ha propuesto. Donde se concluye claramente cuan poco ajustados andan a la verdad los que ahijan esta guerra a la Compañía. Mejor dijeran que la ruina que se ve hoy, y miserable consumo de noventa mil indios, que ha treinta años, poco más, que matriculados se 
reconocieron sirviendo a los españoles, ya hoy reducidos a mil, les ha inducido a buscar el logro de su conservación.

La misma calumnia pudieran haber puesto en el suceso de la nación Guaycurús, que son cuatrocientos indios, que habitan las tierras fronterizas del Paraguay que divide el río; y confinan con la nación Itatí, que son de la jurisdicción del Perú. Esta nación no la han podido sujetar los españoles; antes aquellos tienen a estos muy amedrentados, por ser sumamente belicosos, haciéndoles continuos daños, robándoles los ganados, destruyéndoles sus labores y sementeras, llevándose hurtadas las mujeres, y entre ellas una hermana del más insigne Gobernador que tuvo aquella tierra, que fue Hernandarias de Saavedra. El cual invitó a la Compañía se encargase de domesticar aquella gente; en que fundó la paz de aquella república, ofreciendo en nombre de V.M. cuatrocientos pesos para el sustento de dos religiosos. Ejecutóse así. Entraron dos Padres por aquellas tierras de tan bestiales indios, que sin hacer sementeras, sembrar ni recoger cosas, andan vagando por aquellos campos, llevando consigo unos pellejos que les sirven de casas, y arman a las orillas de las lagunas para sustentarse de pescado y caza. Hay por toda aquella tierra para cada hora del día su especie de mosquitos, y para la noche otras . Esta gente trataron estos religiosos de reducir. Las incomodidades, trabajos y necesidades que padecieron, no puede la imaginación llegar a imaginarlo. No fue más fácil de vencer la contradicción de los indios, que, recelosos de los españoles, concebían descrédito de los Padres. A cuya perseverancia vencidos ya los indios se redujeron a población casi a vista de la ciudad, el río en medio. Cesaron los robos de caballos, destrucciones de estancias, ruinas de sementeras; abrieron puerta a que los españoles entrasen seguros por sus tierras a recoger el ganado vacuno de que abunda aquella tierra. Con esta paz cesaron centinelas; dormían con seguridad los españoles; iban sin los pasados recelos a sus labranzas; quedaban seguras en ellas sus mujeres. Duró este sociego y paz todo el tiempo que a los religiosos les fue permitido estar entre los indios, con harto fruto de los hijos y gente moza; que los ya de edad, envejecidos en su modo de vivir antiguo, dábales en rostro la virtud. Hicieron los PP. arte de la lengua, para facilitar su estudio; escribieron la Doctrina cristiana, compusieron sermones, con que corría la fe con próspero suceso. Llegó un Prelado a aquella iglesia, ignorando los trabajos pasados que habían causado aquellos indios a la república. Vio sólo la paz presente; puso los ojos en los cuatrocientos pesos.

Sirva de confirmación de esta verdad el caso siguiente: La ciudad de la Concepción del Río Bermejo era una, quizá la más florida, de más comercio y expectación de aumentos que hubo en aquellas provincias, por la abundancia de algodón, cera, lienzos, cáñamo y otras cosas, que traían mucho número de marchantes. Tenían allí V.M. una muy lucida población de indios, que daba a la Real Hacienda numerosas entradas de dinero en obrajes; y al paso que se iba acrecentando el comercio, se iba acrecentando el trabajo de los indios de este pueblo y otros, que estaban a cargo de sus encomenderos, todos doctrinados por varios sacerdotes. Rendidos ya totalmente los indios al trabajo, intentaron sacudir el yugo de sus hombros. Convocaron los indios gentiles sus vecinos; y dando de repente en los españoles, mataron algunos, y uno o dos sacerdotes. A otros pusieron una rueca para que hilasen, ejercicio en que decían haberlos molestado. Apoderándose de la ciudad y haciendas, haciendo gran destrozo. La gente española se recogió toda a un convento de religiosos, donde guarecieron sus vidas, zahiriéndoles los indios con los agravios que publicaban haber recibido de ellos. El único remedio fue huir; porque las ciudades vecinas recelaban en sí el mismo daño, y así no pudieron socorrerlos. Salieron huyendo y lastimosamente; las mujeres y niños a pie descalzo por aquellos campos, necesitados del abrigo y del sustento, quedando sus enemigos ricos de 
despojos. A quien cegó con providencia el cielo para que no los siguiesen, que les hubiera sido fácil despojarlos también de las vidas. Con este afán llegaron a la ciudad de San Juan de Vera [de las Siete Corrientes], donde el suplicante los vio, bien lastimado de verlos ayer tan prósperos, y ya tan miserables que pedían limosna. El Gobernador del Puerto envió dos veces ente en buen nfmero al castigo de os delincuentes y reedificación de la ciudad; pero ni lo uno ni lo otro tuvo efecto. Antes volvieron huyendo los soldados, dejando a los enemigos ochocientos caballos, con que se fortalecieron y quedó toda aquella tierra perdida. Pregúntese si se halló aquí alguno de la Compañía? ¿Si tenía a su cargo alguna Doctrina? ¿Si en la ciudad tenía algún colegio? ¿Si tuvo alguna vez alguno de ellos trato o conversación con aquellos indios, para poderse presumir que, por haber puesto mal a los españoles con los indios se rebelaron? No causan, Señor, aquellos alborotos religiosos que por su instituto profesan evitarlos.

Amplíese más este punto. A los Césares pretendieron conquistar los españoles. Entraron con grandioso aparato por sus tierras. Pero escarmentados en los indios de Chile sus vecinos, no quisieron recibir el yugo; y no hubo allí religioso de la Compañía que les hablase mal, e indujese a no recibir a los que pretendían conquistarles. Y así despidieron los españoles de sus tierras, los cuales usando de cordura, dejaron la empresa como imposible. A la provincia del Chaco entraron también conquistadores. Dejáronlos vivir los indios en sus tierras todo el tiempo que no experimentaron pesadumbres. Pero viendo sus tierras penetradas, trasegadas sus haciendas, apetecidas sus hijas y mujeres; se juntaron en tan grande número, que reconocido por el gobernador de aquella conquista, dando una gran palmada dijo: Vive el cielo que de esta vez pongo en España doce mil ducados de renta. Entendiendo mal que los indios venían a darle la paz. Cuando llegando a supresencia los embajadores, le dijeron que ya había diez años que estaba en sus tierras; que tratase de salir de ellas, y dejarlos gozar de su libertad. Y aunque el gobernador, mostrando esfuerzo, les mostró mucha pólvora y balas, valióle poco la estratagema. Porque aquella noche le cogieron los indios todos los ganados, caballos y mulas; conque les fue fuerza hacer su retirada a pie. Y no hubo entre los indios religioso alguno de la Compañía, a cuya persuasión pudiesen hacer este desacato. El pueblo de los indios Chanás que estos años se levantó, y desvergonzadamente negó la obediencia a los españoles, que tantos años había conservado y ya libre del yugo, por sus tierras les hacía daños, no se levantó porponer mal con ellos a los españoles los religiosos de la Compañía; porque nunca esos los doctrinaron, sino otros religiosos.

\section{Visitas de los Obispos}

La tercera calumnia es que no quieren los de la Compañía que los Obispos visiten sus Doctrinas.= Esto es sin fundamento. Porque el Obispado del Paraguay ha sido desgraciado en sus Obispos, porque casi siempre vive viuda aquella iglesia. Don Lorenzo de Grado estuvo allí tan poco, que apenas tuvo lugar de visitar sus arrabales. Siguióle Dr. Fr. Tomás de Torres; y apenas puso allí el pie, cuando fue fuerza acudir al concilio que se convocó en los Charcas; y no volvió más, porque se quedó, y murió electo Obispo de Tucumán. Después de; otra vacante, fue D. Cristóbal de Aresti, el cual llamado de los religiosos, y aún importunado, por el escrúpulo de tener tanta gente en sus reducciones por confirmar, fue luego a visitar las Doctrinas de su jurisdicción. De cuya Visita dio cuenta por sus cartas al Real Consejo de Indias, en que escribe con honorificencia los trabajos de los religiosos; cuan bien doctrinadas tenían sus ovejas, la música en la celebración de las misas y culto divino; aseo, limpieza de los templos. Luego que el suplicante bajó de la Provincia de Tayaoba al Paraná con once mil almas 
sacadas de las uñas de los portugueses, volvió el dicho Obispo a hacer su Visita a estos indios advenedizos, y a los ya antiguos habitadores de aquella tierra. Celebró su Visita, con justos sentimientos de ver aquella iglesia perseguida y acosada de los portugueses. No tuvo más para otra Visita, porque fue promovido al Obispado de Buenos Aires; y desde entonces esta vacante aquella silla; porque a Fr. Bernardino de Cárdenas, Obispo electo años ha de aquella iglesia, el año pasado le fueron las Bulas. A don Fr. Cristóbal de Aresti, ya en su Obispado de Buenos Aires, es testigo el suplicante se le pidió varias veces fuese a visitar las reducciones de su jurisdicción; y el suplicante le instó algunas veces a ello; los mismos indios bajaron al Puerto con sus embarcaciones a llenarlo (para obligarle); de que se excusó por los peligros del río, por su mucha edad y poca salud. En lo que se funda la calumnia es en el siguiente caso que pasó así. Tomó la Compañía dos puestos en los indios Itatines, fronterizos a tierra del Perú, para ir ganando aquella inmensa gentilidad al gremio de la Iglesia y servicio y devoción de V.M. Pusieronse allí tres socerdotes. Corrió la voz entre los gentiles; y entre los que acudieron a la novedad, fue una nación ferocísima llama Payaguá, crueles enemigos de los españoles, en quienes han ejecutado atroces muertes, cautivando sacerdotes, sirviéndose de ellos desnudos con bárbara inhumanidda; con que se han hecho terror de toda aquella tierra, sin ser posible sujetarlos por las armas; y aún se desesperaba poderlos domesticar por el Evangelio; tanta fue siempre su barbaridad y dureza. Estos reconocieron en el religioso trato de los Padres que debían ser otra especie de hombres; viendo la enseñanza de los indios, frecuentes sermones y doctrinas, se aficionaron a la virtud, que aún a las bestias rinde. Comunican ya mucho a aquellos Padres (aunque los dos rindieron ya las vidas en lo más florido de la edad a manos de trabajos; para suplir esta falta dejó un religioso la cátedra de Artes que leía, prueba del concepto que hace la Compañía de la conversión de los gentiles). Estos Payaguás, han pedido a los Padres que quieren ser cristianos y reducirse a pueblos, deseosos de que sus hijos gocen de la enseñanza que los demás habitadores de aquellos pueblos. Pidieron los religiosos y su Provincial al Obispo fuese a confirmar los ya cristianos: deseó hacerlo; pero es testigo el suplicante que no hubo clérigo ni secular que quisiese acompañarle de miedo de los Payaguás. El P. Justo Mansilla (a cuyo religioso trato y de sus compañeros se habían rendido aquellos bárbaros) pidió con instancia varias veces al Obispo esta Visita, asegurándole su vida y las de todos los que le acompañasen; y aún se obligó a que los mismos indios de quien tanto temor tenían, los llevarían y volverían con toda seguridad. Lo cual se echó a engaño, interpretando que dificultad tan grande la minoraba la Compañía con traza de que no dando crédito a ella, cesase la Visita. Mal infirieron: y antes se saca la consecuencia clara que no impiden los de la Compañía las visitas de los Obispos, pues con tanto ahinco procuraron esta, y consiguieron las otras antes dichas.

\section{Visita de los Gobernadores}

Dice la cuarta calumnia que los religiosos no dejan que los Gobernadores vayan a visitar los indios.= No es creíble, Señor, que Gobernadores en las Indias, y tan lejos de V.M., sean tan humildes, que se dejen sujetar de unos pobres religiosos, y tan sujetos a cualquiera señal de los mandatos de V.M. y sus ministros, principalmente siendo ya cosa bien conocida que los Gobernadores, mientras $\mathrm{m}$ s se apartan de la soberana grandeza de V.M., en cuya presencia son invisibles, van aumentando m s su estimación: en tanto grado y con tanta soberanía, que cualquiera simple proposición a sus órdenes, aunque no sean ajustadas, se reputa por resistencia a la justicia. Y si hubiesen sucedido algunos agravios, quitándoles a los indios sus embarcaciones, haciéndoselas llevar muchas leguas a ellos mismos, costeándose ellos mismos su sustento, sin que el Gobernador les gratificase ni el trabajo de llevarlas, ni el precio de ellas, que les quitan 
para sus intereses: no se puede decir que es resistencia el avisarle de este agravio, ni del mal ejemplo que se sigue de él: ni del impedimento que estas acciones y otras peores, ponen al Evangelio; ni por esto ha de decir el Gobernador que le vedan la visita de su distrito. Poder tiene el sacerdote para reprender los vicios: y a ningún Gobernador se ha hecho con descortesía. Algunos, si, la han afectado con los sacerdotes. Que vayan visitado las veces que hayan querido, es infalible verdad. El Gobernador Hernando Arias visitó a S. Ignacio e Itapúa, luego que se fundaron por la Compañía: y en su gobierno no se fundaron otras. Manuel de Frías, don Luis de Céspedes, las visitaron sin contradicción: y siendo este llevado preso a Chuquisaca y privado del gobierno, envió la Audiencia de Charcas otro en su lugar, Martín de Valderrama. El cual, lo primero a que atendió fue a empadronar los indios: a que el suplicante se halló y trabajó en sosesgarlos, por los agravios que recibieron de los soldados que llevó consigo (que siempre son en buen número), por que no había ni mujer, ni hija, ni cosa segura a su apetito: y es testigo el suplicante que por haberle dado éstos y otros avisos importantes al desempeño de la conciencia de V.M. y de la suya, convocó de secreto los caciques en su casa, y les persuadió a que le pidiesen en público que echase de allí aquellos Padres, e hizo otras diligencias bien opuestas a su oficio.. Estas escandalosas acciones encendieron más a los indios el amor de sus Padre, confesando deberles todo el ser que tenían de cristianos. A este Gobernador siguió don Pedro de Lugo: y con haber poco que se había hecho el padrón, lo volvió a hacer, sin contradicción de nadie, antes con mucho aplauso y fiesta que le hicieron: y sin replicar los indios a los agravios que reciben, y gastos excesivos a su pobreza, con tanto acompañamiento de soldados que llevan consigo los Gobernadores. Todo lo cual consta por las Visitas que hicieron y padrones. Luego, falso es decir que los religiosos no quieren que visiten los Gobernadores. Los Gobernadores dichos lo han sido del Paraguay. Los del Puerto de Buenos Aires nunca los han visitado, porque nunca han sido de aquel puerto: y rara vez alguno ha visitado las poblaciones de españoles de su gobierno.

\section{Tratos y contratos}

La quinta calumnia es que los Padres tienen tratos y contratos y con esto tienen ocupados los indios.= Sea testigo de la falsedd de esto la Majestad de aquel Señor que es Juez de vivos y muertos, a cuyo tribunal fuerza [sic] la pasión que lo ha inventado. Sea testigo entre otros que presentar el suplicante si se le mandare, D. Lorenzo Hurtado de Mendoza, Obispo electo del Río Janeiro, persona que ha habitado el Occidente muchos años. El cual, movido de la extrema necesidad de dichos religiosos que con mucha razón se pueden llamar apóstoles de aquella gentilidad, les juntó socorros de limosnas, siendo administrador en los Chicas. Y avecinándose más, siendo Prelado en la jurisdicción del Río Janeiro, vio algunas veces los dichos religiosos caminar a pie muchas leguas en busca de los indios, descalzos, rotos, sin llevar otro ajuar o repuesto que que una hamaca o red para dormir, sustentándose con raíces de mandioca: tan flacos, tan descoloridos y acabados, que $\mathrm{m}$ s parecían retratos de la muerte que hombres vivos. Mal dice tanta pobreza con el interés de contratos que publican émulos, si bien lo que su malicia finge, aprueba la verdad. Cómpranles los Padres a los indios la voluntad a precio de trabajos para que se reduzcan, a cosa de continuos desvelos para doctrinarlos y hacerlos tan doctos como son en la doctrina: con ajustarse hombres tan letrados a la pequeñez de sus ingenios: con perseverancia en sufrirlos y sobrellevarlos. Con esto los rescatan del gentilismo para hacerlos esclavos del demonio, hijos libres de Dios. Será bien, Señor, que sean examinados testigos: y pregúnteseles ¿qué casas habitan estos religiosos? Son una pobres chozas pajizas. ¿Qué ajuar poseen? El Breviario y Manual para bautizar y administrar Sacramentos. ¿Qué sustento tienen? Raíces de mandioca, 
habas, legumbres: y es testigo la Majestad de Dios, que en pueblos de gentiles se pasaban veinticuatro horas en que el suplicante y sus compañeros, ni aún raíces comían, por no pedirlas a los indios, recatando el serles cargosos, trabajando con ellos todo el día, en catequizar, predicar, bautizar, confesar, y curar sus almas y cuerpos: a cuyos trabajos rindió el alma en manos del suplicante, el P. Martín de Urtazum, nobilísimo navarro, que renunció, por morir en los brazos de tan apostólica pobreza: la cual al suplicante y sus compañeros tuvo ya a pique de entregarlos a la muerte. A la misma rindió al P. Diego Ferrer, y P. Nicolás Ignacio esta pobreza, y otros muy lucidos sujetos, a quien no la edad, porque eran mozos, sino la misma miseria de dormir sobre un poco de paja o algun pellejo, los arrebató. Averígüese, Señor, esta verdad: sáquese en limpio. ¿Quién sirve a V.M. con ver s? ¿Quién le reduce vasallos a costa de su vida? ¿Quién le ofrece los tributos, ajenos de intereses propios? ¿Quien le defiende sus tierras sin estipendio? ¿Quién le busca soldados indios que las amparen? Cuantas veces, encontrándose el suplicante con tropas de protugueses, fue maltratado de ellos, y puesto ya para ser peloteado con sus arcabuces, no por otro delito que defender las tierras de V.M. y sus vasallos indios, sin otro interés que el amor tan debido a V.M.: y por confesar el debido vasallaje que se le debe, negándolo ellos, y afirmando tener su rey. De quedos años antes del alzamiento de Portugal, puesto el suplicante a los Reales pies de V.M. las primera vez, dijo estas palabras: Señor, desde aquellas remotas provincias he dado voces con cartas a esta Corte, manifestando los intentos de los portugueses, y por la distancia que hay de tantas leguas no he sido oído: y así vengo a los reales pies de V.M. a pedir el remedio de los males gravísimos que justamente se temen. Pretenden Señor, quitar a V.M., la mejor pieza de la Corona que son las Indias.

Dentro de dos años se rebeló Portugal, y ha cuatro que el suplicante asiste en esta Corte, con hartos sufrimientos, sin otro interés que hacer servicios a V.M. Averígüese, Señor, y sépase quien apoya las acciones portuguesas, quien contradice las armas de fuego que el suplicante ha pedido con instancia para los indios (ya fnico remedio, como se ve en el n.1 y 2),para lo cual ha ofrecido el suplicante que la limosna que V.M. da a los religiosos se emplee en eso. Y si fuere necesario, tiene ofrecido en sus memoriales vender los ornamentos de las casas de su provincia, para el mismo fin, con deseo de que toda aquella tierra conserve la lealtad a V.M., pues de ella depende el conservarse en la fe católica. Y conocidos quien son claramente, se conocer que son los inventores de estas calumnias.

Averiguada ya, Señor, no la pobreza que oprime a los religiosos, sino la miseria y desnudez con que sirven a Dios y a V.M.: averígüese el tesón y cuidado con que aprenden en todas las Indias las varias lenguas que hay, con tanta perfección que les parecen nativas. Todos cuantos sujetos hay allá y V.M. con su Real liberalidad envía, aprenden las lenguas: y hay sujetos que saben dos y tres de indios: y en partes donde hay frecuencia de negros, como en Buenos Aires, Córdoba y otras partes, hay lenguas de negros: de que han hecho artes y libros, para que se vaya conservando este santo arbitrio: con que se ganan muchas almas de negros: que, si son ladinos se confiesan más claramente y sin empacho; si bozales, se averiguan sus bautismos, se catequizan y saben la doctrina, en que se han hecho muy grandes servicios a Dios. Y para que conste de esta verdad, hay órdenes de los PP. Generales, que inviolablemente se guardan, que ningún sacerdote de la Compañía haga su solemne profesión, aunque sea aptísimo para ella, si no supiere alguna lengua de indios o negros. Y el suplicante ha impreso los libros que en el número 5 dice, haciendo fundir caracteres diversos para diversas pronunciaciones. Y no se atribuir a inmodestia el referir estos servicios, cuando no se atiende al interés y premio, sino a satisfacer a calumnias, que una religión ofendida a los 
Reales ojos de V.M., tan benemérita de su Real servicio, acosada de calumnias (que vestidas de religioso traje pretenden arrebatarle el crédito), haga reseña de servicios, usando de violencia en reprimir lo que en descrédito de sus émulos pudiera lícitamente publicar.

\section{Servicio de los españoles}

17. La sexta calumnia es que los religiosos no quieren que los indios sirvan a los españoles en servicio personal.= Esta queja, Señor, no es ya contra la Compañía, sino contra V.M., contra los señores Reyes sus progenitores, contra sus Reales Cédulas, contra Ordenanzas de Visitadores Reales, que son casi infinitas, ya ellos les son muy notorias, en las cuales expresamente manda V.M. se quite el servicio personal, descargando su Real conciencia con las de los Obispos y Gobernadores: mandando asimismo que, pagando los indios el tributo que se les impusiere, vivan libres en sus pueblos, como los demás vasallos de V.M. Con que está respondido a este punto. Y cuanto al tributo, los indios que la Compañía ha reducido, nunca han sido tasados. Porque cuando Don Francisco de Alfaro, Oidor que fue de los Charcas, con mandato de V.M., visitó aquellas provincias, no habían entrado dichos Padres a la espiritual conquista de dichos indios. Y habiendo ya pasado los diez años que V.M. concede libres de tributo a los convertidos a nuestra santa fe desde su conversión: siendo D. Pedro de Lugo Gobernador, le hizo notorio por parte de la Compañía el P. Diego de Alfaro, rector del colegio de la Asunción, como habían ya cumplido algunos los diez años, pidiéndole diese orden que pagasen el debido tributo a V.M., y el dicho Gobernador respondió que no le pertenecía a él eso, sinó al Visitador que V.M. enviase a la Visita y tasa de dichos indios. Y pues el Gobernador se excusó con tan justa causa, de que ningún cuerdo le pondrá culpa; mucho menos la pondrá él a los religiosos, a quienes sólo incumbe buscarlos por los montes, reducirlos a pueblos, enseñarles nuestra santa ley, bautizarlos y conservarlos en ella, y tenerlos expuestos a la Real voluntad de V.M., a quien reconocen por su señor. Pero que de todo punto se deshaga esta calumnia, consta de Memoriales, y de quince veces que el suplicante, en espacio de cuatro años que asiste en esta Corte, entre otrs cosas ha pedido a V.M., que se nombre Visitador (¿y Comisario?) que los visite y tase. Y mostrándose V.M. tan señor de aquellas Indias cuanto desinteresado de ellas, en tres años no ha querido responder a este punto, hasta que, instando el suplicante se tasen y tributen: pidiendo que con estos tributos sean gratificados algunos vecinos, hijos de conquistadores, teniendo atención a sus servicios: V.M. se ha servido de remitir la Visita al Obispo y Gobernador, añadiendo con su real benignidad que los indios, los ya convertidos, como los que se convirtieren, no paguen tributo alguno en veinte años. Con lo cual parece que queda deshecha esta calumnia.

\section{Conquista por armas}

18. La séptima, que los dichos religiosos conquistan los indios por armas.= No dejar de dudar ya aquí alguno que tan atentos reparos en ajenas acciones, dejen de llevar algún interesado fin o de desdoro ajeno, o de interés propio. Léanse las historias de los religiosos que en aquella provincia han padecido martirio: léanse las informaciones que por orden del Ordinario se han hecho: y se ver claramente que sin ayuda de español alguno, se entraron por aquellas tierras de gentiles, llevando por armas una cruces en las manos, que juntamente sirven de báculos. Y si después de haber experimentado agravios de los gentiles, poca fe en su palabra de recibir pacíficmente a los predicadores del Evangelio, llevan indios amigos que los defiendan: ¿quien dudará que eso sea muy lícito? Si absolutamente dicen que los religiosos hacen guerra a los indios, para forzarlos a recibir nuestra santa fe, es intolerable ignorancia o sobrada malicia juzgar 
que aquellos religiosos ignoran el modo que Cristo nuestro Señor dejó a sus Apóstoles de predicar e introducir su Evngelio (Suar. de Fid. tract. 1 disp. 18 sect. 1 n.10. Id. disp. 18 De Bell. sect. 5. nn. 7 et 8 Maior, in 2. dist. 44. q. 2.). Si alguna apariencia tiene esta calumnia, fúndase en que habiendo el suplicante varias veces solo y sin armas, con solos quince indios amigos, acometido a la grandiosa provincia de Tayaoba (que fue el mayor cacique que se vio en aquella región, inexpugnable por las fragosas sierras, arrebatados ríos, montañas muy espesas) a hacer rostro, con la verdad del Evangelio, al mentiroso culto con que el demonio se hacía adorar en huesos secos de indios, que en vida fueron sus discípulos y en muerte los hacía honrar por dioses en templos que les fabricaban los gentiles, donde colocados acud; an a sus falsas adoraciones y sacrificios, pidiendo a tan mentidos dioses el remedio de sus necesidades: donde en guerras se mataban y comían tan frecuentemente, que discurriendo por aquellas partes el suplicante, topando ollas grandes de carne ya cocida, juzgando ser de javalís, comió alguna vez, y sus compañeros, carne humana: hallando después los pies, manos y cabeza de hombres: donde finalmente era imposible que las armas abriesen camino a sujetarlos, como el suceso mostró algunas veces. A esta provincia acometió con el Evangelio varias veces con peligro de la vida, de que fue repelido, escapando por muy espesos montes con pérdida del ornamento portátil, su único ajuar, sin que correspondiese a tan justo y repetido deseo buen suceso alguno. Buscó prestadas cinco escopetas, y con veinte indios amigos volvió a aquella leonera. Fabricó con toda diligencia en un descollado campo, que señoreaba gran parte de aquellas tierras, un fuerte de madera a la usanza de la tierra. Fabricó dentro casas pajizas, y un largo galpón, para ostentación de fuerza.Al silencio de la noche hacía disparar a compás las escopetas; $\mathrm{y}$ en buen número de tiros, que resonaban por aquellos campos y montes. Entraron en cuidado con esta estratagema los gentiles, juzgando había en el fuerte grandes prevenciones, y fuerza inexpugnable. Juntáronse como número de tres mil flecheros, que acudieron a reconocer el fuerte; y atemorizados con la apariencia, se retiraron. Ya por curiosidad de ver al suplicante, acudieron particulares caciques, que los recibía en la puerta, por no hacer patente su poca fuerza. Estos convencidos con fuertes y amorosos razones, y algunas cortas dúvidas de anzuelos y cuentas, dieron oídos a que el fin de esta estratagema y prevenciones no pretendían más que su salud eterna por medio del santo Evangelio. Conocido este intento, dieron en acudir muy grandes tropas de hombres mujeres y niños llevando su pobre ajuar para poblar allí, dejando sus quebradas, sus cuevas, y sus escondidos alojamientos; con que en muy breve tiempo se fundó una lucida villa de mil vecinos. A cuya emulación, sin ser necesario repetir estratagemas, venían de las interiores provincias a pedir que en ellas se fundasen semejantes poblaciones. Y así se hicieron algunas más numerosas, de a dos mil y tres mil vecinos. Este fundamento tiene esta calumnia; de que librara al caso cualquier juez desnudo de pasiones. Y si la ceguedad de los émulos no les privara de la razón, bien pudieran reparar en tan heróico acto de caridad, en la terrible hambre que se padeció en aquel fuerte: pues el sustento de muchos $d_{i}$ as fueron yerbas silvestres, y raicillas aún no usadas por las bestias. En el alojamiento tan pobre, que las camas eran un poco de paja, en un bien riguroso invierno. En los recelos contínuos de perder la vida; pues si el cielo no les hubiera cegado a los gentiles, treinta solos bastaban para quit rsela. En el premio que la fe podía esperar en tierras tan remotas, tan sin testigos. $Y$ no es pequeña providencia del cielo el permiso de esta acusación, para que estas verdades, que ocultas quedaban ya en las manos del olvido, las libre de él tan justa defensa.

\section{Armas de fuego a los indios}


Hacen mucha fuerza diciendo que la ocmpañía comete grave caso en dar armas de fuego a los indios, que es la total ruina de aquella tierra; sobre que se han actuado papeles.= La proposición en parte es falsa. Porque si bien la Compañía ha procurado que las dé el que puede, porque con verdad juzga el único remedio para asistir a los rebeldes; el Gobernador D. Pedro de Lugo se las dio: y nadie condenar el hecho, sino la facilidad en concederlas para resistir al enemigo y la inconstancia con que, felizmente resistido, condena su misma acción de haberlas dado, exagerando el caso con decir que los indios tienen fraguas en que se forjan escopetas y se labran armas.- A esta calumnia está en parte respondido en el número 1 y 2 ; pero ser necesario añadir algo en éste. De la lealtad a V.M. de los portugueses de S. Pablo, siempre se dudó. De sus intentos de conquistar el Perú, consta por los papeles auténticos y cartas de la Audiencia de los Charcas, y de otras personas celosas del servicio de V.M., por las cuales consta haber llegado al paso de Santa Cruz de la Sierra, tierra ya vecina a Potosí. Que la villa de S. Pablo y otras circunvecinas echen cuatro o cinco compañías de cuatrocientos y quinientos hombres mosqueteros con cuatro mil y mías indios flecheros, gente muy belicosa y bestial, es cierto; porque el suplicante y otros religiosos sus compañeros los han visto varias veces por aquellos campos marchar con mucho orden de guerra, en que est $n$ muy ejercitados; y tanto en andar a pie y descalzos, que, como pudieran andar por las calles de esta Corte, caminan por aquellas tierras, montes y valles, sin ningún estorbo, trescientas y cuatrocientas leguas; sin que jamás les falte la comida, porque saben coger el tiempo en que los piñones están sazonados y los parajes donde han de hacer provisión; saben las poblaciones de los gentiles, de cuyas labranzas se sustentan y previenen para adelante. La miel silvetre es mucha, y la diligencia de los Tupís en buscarla es rara. Con que caminan con regalo. Y así ha sucedido a estos portugueses estar tantos años ausentes de sus casas, que juzgados ya por muertos a manos de los indios, se casaron sus mujeres; y volviendo vivos, hallaron ajenos hijos, llevando ellos los que en las indias gentiles procrearon. La resistencia a esta gente se refunde en sola la ciudad de la Asunción, que sola ella y otros pocos españoles, residuo de tres ciudades, que los portugueses destruyeron, forman un Obispado y un gobierno. Los españoles que incluye este gobierno se duda si pasan de cuatrocientos; y cuando de estos haya trescientos; y cuando se estos haya trescientos que puedan manejar armas, será mucho. Son muy buenos tiradores de escopetas, pero nada ejercitados en caminos; porque son buenos jinetes, y a pie no dan un paso. El ocio y paz con que han vivido, atendiendo sólo a defenderse de los indios guaycurús y payaguás, y el agasajo y regalo de sus casas, les es impedimento para discurrir por pantanos, breñas y montañas en busca del enemigo; y el ser éste tan pujante, como ya se ha dicho, hace temeridad acometerle o seguirle, cuando es imposible con tan corto número de soldados hacerle resistencia. Y si cunado reputados estos portugueses por vasallos de V.M. se hacía este discurso para la seguridad de aquella tierra, ahora que tan libremente ya han hecho plaza de sus dañados designios, ¿qué juicio se hará en tan apretado caso que obliga a buscar remedio o entregar la tierra? De la lealtad de los vasallos de V.M. en aquel gobierno; no hay lugar a duda, porque primero ofrecerán sus cuellos al cuchillo, que macular su lealtad, heredada de la noble sangre de sus progenitores. Que por este fin perezcan, ningún útil se halla al servicio de V.M., principalmente pudiendo darmedio en la seguridad de sus vidas y de aquella tierra, sirviéndose V.M. de sus vasallos indios armándolos con instrumentos de fuego, que sus armas antiguas de flechas, garrotes, piedras y otras ningún daño pueden hacer al enemigo. Si de su valor se duda, ya se vio en el n. 1 y 2 cuan bien se manifiestan. Si de su lealtad, que es el reparo común, no parece hay duda, porque gente que con tantas veras abrazó nuestra fe Católica, conservándose en ella tantos años con tan gran firmeza, que hasta hoy se ha visto alguno que haya apostatado, 
antes han muerto algunos a manos de sus mismos parientes gentiles, en confirmación de la ley que recibieron. Y no pocas veces ha sucedido que, entendiendo el precepto divino de no matar a la letra, pudiendo ellos matar muchas veces a sus enemigos, portugueses. se dejaron antes cautivar y haceer esclavos, y padecer división de sus mujeres e hijos, pérdida de sus haciendas, destierro de sus patrias, por no quebrantar (así lo pensaban) el quinto precepto del Decálogo. Afírmalo así el suplicante como testigo de vista, y experiencia que tiene de casi treinta años. Y no es menor argumento de esta fidelidad, que ofreciendo los portugueses a estos indios cristianos libertad de conciencia, y permiso libre de vivir al modo que vivieron en su gentilidad, con multiplicidad de mujeres (así dejan vivir a los Tupís de que se sirven), y los demás vicios que a la deshonestidd acompañan; a que por este medio se les entreguen, y concibiendo horror a un bautismo, un matrimonio, y a una sola mujer, desamparen nuestra fe y aborrezcan a los religiosos, que con yugo suave los unen a su Criador (consta de los papeles que se presentaron en la Junta): siempre han huído de tan perniciosos enemigos, por conservar la ley que recibieron. Prueba es esta, Señor, de gran lealtad a Dios: y quien al Rey del cielo muestra esta fineza, no hay duda que la guarde al de la tierra. No ha sido el menor motivo para reducirse a pueblos la noticia que tienen de la grandeza de V.M., su justicia, su benignidad y el amparo que da a los que se amparan de su Real nombre. Y es tan asentada verdad ésta, que a sola esta voz de un Gobernador: El Rey me envía; se humillan, rinden y sujetan de manera, que cualquier agravio que éste les haga lo llevan en paciencia; y ni aún a pensar mal contra los Gobernadores se atreven, aunque los desuellen, por veneración sola del que los envía. Véanse las historias, y ellas digan si algunos indios se rebelaron e hicieron daño a los españoles antes de haber sufrido de éstos insufribles agravios. En el Tucumán noventa mil indios que se entregaron a los españoles perecieron en treinta años a sus manos; y unos pocos que habitan aquellos campos, libres de este yugo, se conservan hoy, y aún se aumentan. Y en las demás provincias se puede hacer el mismo cómputo; pues casi no hay parte o lugar de toda la América donde no están dando testimonios de esa verdad las poblaciones de indios deshechas, consumidas sus vecindades, acabadas sus familias, y muchos pueblos y lugares que, habiendo sido muy numerosos pocos años ha, están hoy tan despoblados y destruídos, que apenas ha quedado en los paredones y ruinas de sus casas rastro de lo que fueron. Todo el Perú prueba esta verdad; y muy en particular el Reino de Chile, donde en toda la tierra de paz que poseen los españoles, sirviéndose de los indios, apenas han quedado muy pocos; y los que sacudieron el yugo de su pesada servidumbre, sin embargo de lo que les ha consumido la guerra, que han sustentado más de cuarenta y cinco años, se han conservado y aumentado en tanto número, que según consta de la relación que envió a V.M. el año pasado el marqués de Baides, Gobernador y Capitán general de aquel Reino, pasan de cien mil los que dan la paz, fuera de otros, muchos que en la tierra más adentro aún no la han dado. Y ninguno huye de la sujeción y amor que deben a V.M., sino del pernicioso tratamiento con que los consumen. Y dado caso que la voluntad de los indios flaquease contra los españoles hoy no necesitan de escopetas sino sólo de convocarse solos los cristianos, que son en muy buen número. Y si solos cuatrocientos guaycurús gentiles tienen a raya a los españoles, y aún si quisieran los hubieran ya consumido y muerto; que harían si se juntasen cristianos y gentiles? Y dado caso que necesitasen o quisiesen usar delos mosquetes, les es imposible: como muy bien advierte el Cabildo ecco. del Paraguay en su carta, y el Padre Miguel de Ampuero, Rector de la Asunción, en sus escritos, de que de todo se hace presentación. Y el suplicante también tiene hecho informe a cinco Tribunales que ha sido remitido. Porque totalmente faltan los materiales para fabricar la pólvora; y plomo no [le] hay en toda aquella tierra. Esto está ya confirmado en el Reino de Chile; donde los indios han 
cogido buena cantidad de escopetas; y hasta hoy se ha visto usar de alguna de ellas, con tener consigo cautivos españoles y mestizos, que saben hacer pólvora, por no tener la materia de su fábrica. Y la experiencia enseña que los indios leales defienden las tierras de V.M. con estas armas. En el Puerto del Callao de Lima las usan contra los holandeses y otros enemigos, en donde sirven dos compañías de indios con capitanes y oficiales de la misma nación. En Trigo pampa, provincias de Tomina, en Pilaya, en Paspaya, fronteras de infieles, usan de estas armas los indios en defensa de los españoles contra sus mismos naturales, de que se ven muy bien defendidos los españoles, sin que se haya experimentado abuso en el uso de ellas. De donde evidentemente se siguen algunas conclusiones. La primera que la Compañía no dio las armas. La segunda, que el Gobernador las dio. La tercera, que hizo bien en darlas. La cuarta, que hace mal en contradecirlas. La quinta, que en todo caso conviene que V.M. mande se les den, o el Virrey del Perú, a quien V.M. lo tiene remitido.

El tener una ciudad o villa una fragua, no es delito; antes la improvidencia de no tenerla fuera falta, como cosa tan necesaria para la vida humana; sino es que, como obligaron los españoles otros tiempos a los indios gentiles a que de ciento y más leguas acudiesen a aderezar sus cuchillejos y herramientas a sus pueblos, para detenerlos con esto muchos meses y aún años en su servicio, se intentó ahora esto en gente ya cristiana, que de su voluntad se han entregado por vasallos de V.M. Fuera esto muy reprensible. En cuatro pueblos de veinte y cinco que tiene hechos la Compañía, hay cuatro fraguas, en trecho acomodado para que acudan a aderezar sus herramientas. Pero convendrá advertir que los inventores de esta calumnia dan a entender que estas fraguas son al modo de las de Vizcaya: porque oficina donde se fabrican armas (como ellos dicen) de fuerza ha de ser muy cumplida.- Estas que ellos llaman fraguas, no contienen $\mathrm{m} s$ que unos fuelles pequeños, dos martillos y dos tenazas en una chozuela bien corta, donde apenas se pueden aderezar las herramientas sin las cuales es imposible labrar la tierra. Y no se diga que en habiendo fragua ha de haber tanto hierro, que se puedan fabricar armas. En toda aquella tierra del Paraguay, ni en el Brasil, ni en el Perú, hay minas de este metal. Y si en las ciudades despobladas por los portugueses se halló alguna, está ya hoy esa mina en poder de los portugueses. Supuesto pues, que no hay hierro en las Indias, y que el que va de acá a alla es muy caro, y que al Paraguay pasa muy poco por pasar casi todo al Potosí; y que los indios son tan pobres, que el que puede acaudalar un hacha para su labranza, es rico, ¿dónde está la fábrica de estas escopetas, que éstos émulos fingen? Y caso negado que la hubiese, ¿era pequeño servicio a V.M., que ahora se labrasen allí muchas armas, y que por allí hallase el portugués rebelde resistencia al pertinaz intento que tiene de pasar al Perú? Repítase, Señor, el caso referido en el n£m. 1 y 2, que con siete escopetas que dio D. Pedro de Lugo, vencieron los indios vasallos de V.M., quinientos portugueses bien armados, y les quitaron por despojo dos mil indios cautivos que llevaba. ¿Qué hicieran, Señor, si tuvieran dos mil mosquetes? ¿Si se vieran honrados de V.M. y amparados por semejante servicio? Cierre este párrafo una conjetura: que el que trata de quitar las armas a aquellos indios, fieles vasallos de V.M., da indicios de amistad con los portugueses, y de neutral en la deba obediencia y amor a V.M.

\section{Despoblar reducciones}

La nona calumnia es que la Compañía despuebla las reducciones sin licencia, y esconde los indios de los españoles.= El fundamento de esta calumnia es que, habiendo los portugueses asaltado tres ciudades de españoles (de que consta en el Real Consejo de Indias) y llevádose consigo parte de los españoles y casi todos los indios sujetos a 
dichas ciudades: intentaron también llevarse los pueblos que la Compañía tenía y había fundado. Defensa no la había a tan insolente enemigo; y así era fuerza retirar los dichos pueblos. La licencia para este retiro se había de pedir a la Real Audiencia de Chuquisaca: ésta distaba setecientas leguas; el enemigo estaba ya casi a vista de los pueblos. Y así el suplicante y sus compañeros se determinaron a recoger la más gente que pudieron, y retirarse con ella, que fueron en n£mero de once mil almas; y por varios caminos y desiertos, montes y ríos, los bajaron al río Paraná, jurisdicción del Paraguay, en donde algunos distaban doscientas o trescientas leguas, y hoy no distan más que cuarenta o cincuenta leguas: en donde han sido visitados y empadronados dos veces por dos Gobernadores que ha habido después que bajaron de tan lejanas tierras, que por serlo tanto, pretendían los portugueses ser de su jurisdicción. La Audiencia de Chuquisaca, a quien se dio aviso de todo, aprobó la dicha mudanza, y la estimó por servicio hecho a V.M. muy calificado, y tal que cualquier Gobernador que la hubiera ejecutado, con sólo este servicio, viniera a esta Corte a pedir mercedes a V.M. Ocultólo la Compañía con esperar las del cielo, hasta hoy, que la razón le obliga a amparar acción tan noble, cuanto ultrajada de la emulación. Y quitada ésta, se ver claro el servicio que a V.M. se ha hecho. Porque si estos indios los hubieran llevado los portugueses, hoy estuvieran con ellos fortificando sus fronteras, tuvieron ayuda y guía en ellos para las entradas que pretenden al Perú, fueran finalmente amigos de los enemigos de V.M., que sólo haberlos conservado en esta devoción, es estimable servicio. Pero adelántase más; pues hoy están con muy gran voluntad ofreciendo tributos y juntamente sus personas e industria para la defensa de aquella tierra, sin estipendio ni esperanza de otro premio que el real agrado y servicio de V.M. De todo lo cual consta la falsedad de esta calumnia.

Para prueba del intento de este Memorial, hace presentación el suplicante de un exhortatorio que el P. Miguel de Ampuero, Rector del Colegio de la Asunción, hizo al Gobernador D. Pedro de Lugo, en razón de la conveniencia que había de no prohibir las armas a los indios después de haber obrado tan felizmente con ellas. Otro del dicho rector al Cabildo contra Francisco Rivas Gavilán, sobre la denunciación criminal que hizo en el juzgado laico contra los religiosos que defendieron las tierras de V.M. contra sus rebeldes enemigos. Una petición del dicho Rector al Cabildo, en que contradice la dicha denunciación criminal: por donde aparece no haberle querido dar tralado de dicha querella. Otro exhortatorio del mismo al dicho Cabildo, por donde consta la malicia con que buscaban firmas de vecinos, solicitándolas por caminos torcidos, para autorizar sus informes e informaciones contra la Compañía, en raz $\not$ n de las armas que pretenden contra los rebeldes portugueses. Un requerimiento del P. Francisco Clavijo, protector de los indios, digno de que V.M. lo vea, porque por él consta la invasión de los portugueses, el destrozo que de ellos hicieron los indios, y la remisión del Gobernador. Una carta de la Sede vacante del Paraguay en que sin pasión informa de la verdad del caso. Un testimonio del escribano del Cabildo, en que da fe que el Gobernadoro todo caído de viruelas, bautizno le quiso dar los papeles, para que no diese tralado de ellos, con nimo de que sólo los suyos pareciesen en esta Corte, y vese clara la malicia del dicho Gobernador en que dichos papeles vienen autorizados por el Provincial de la Compañía, y no escribano real

Las reducciones que la Compañía tiene son poblaciones que desde sus principios fabricaron sus hijos, reduciendo aquellas gentes bárbaras que imitando a las bestias, vivían por los riscos, valles y quebradas; sacándolos de aquí a poblaciones que de ellos se han hecho, donde los sacerdotes que los juntan, siendo por sus prendas y talentos merecedores de puestos, pálpitos y cátedras, se han sabido ajustar a tanta pequeñez, que, 
dejando aparte la diligencia con que los doctrinan para la vida eterna, aún para la temporal les han enseñado todos los oficios que forman una república: sastres, carpinteros, herreros, con los demás oficios: y no ha sido menos útil el de labrar la tierra con arados; cuyos instrumentos y su uso se lo han enseñado los mismos religiosos con la práctica, con que sustentan sus familias con abundancia. El aseo y limpieza de los templos suple su pobreza. La música e instrumentos con que se celebran los divinos oficios remedan mucho alos de Europa. Y si en la devoción ya justa debida excede, atribúyese a los auxilios con que Dios fomenta aquella nueva planta, siendo instrumentos de este bien los sujetos que V.M. con tanta liberalidad envía a costa de sus reales tesoros. Este fruto tan brevemente referido, trata el Gobernador y mal afectos hombres, que cese. El fin es para que los indios sean siempre bestias, para que sin quejarse sufran los trabajos con que los afligen, de que los Reyes pasados y V.M., advertidos, han enviado casi infinitas Cédulas en su remedio. El medio es el reparo que hacen en el gasto que V.M. hace con los religiosos Curas: sin atención a que la liberalidad con que de las Indias envía Dios a V.M. tan grandes tesoros, es por la franqueza con que V.M. los emplea en su servicio, repartiendo de los tesoros de las Indias ricas del Perú con los pobres del Paraguay y aún sin reparo de que quizá cesando aquellos gastos, cesen aquellos emolumentos.

Y aunque el Gobernador proponga que sin este gasto habrá quien se encargue de estas Doctrinas con el sustento natural que dicen, no es posible que sin grave detrimento de su honor se atreva alguno al cultivo de mies que no sembró. Y si sin interés se ofrece a ello, es cierto que su sustento ha de salir de los mismos indios, con que se les acrecerá nueva carga, y no la menos grave. Si por trabajar en servicio de la Iglesia, aquellas regiones están llenas de gentiles en que podrán ejercitar sus fervorosos deseos, como este año pasado hicieron dos de la Compañía, que despedazados a manos de gentiles acabaron gloriosamente. El año de treinta y uno, con ocasión de un Informe de ministros celosos del servicio de V.M., se trató de que la Compañía tomase algunas Doctrinas que se pretendían quitar, a que en ninguna manera asintió su modestia. Pero ya que el arbitrio del Gobernador y Cabildo seglar del Paraguay es que se ponga estanco de Doctrinas, a rebaja de la limosna que V.M. da, se haya de admitir: se debe, Señor, advertir, que la conquista de aquellos indios costó a la Compañía diez y seis hijos sacerdotes de aventajados talentos, que han muerto los siete de ellos con atroces muertes a manos de gentiles, en odio de nuestra santa Fe: otro a escopetazos de portugueses, cuya muerte ha calificado la Universidad de Salamanca y la de Alcalá, y otros particulares maestros, por martirio. $\mathrm{Y}$ aunque los demás no murieron al rigor del cuchillo, pasaron de esta vida por grandísimo trabajos, desterrados de sus deudos y de sus patrias en tierras tan remotas; además para buscar cincuenta sacerdotes lenguas, será menester esperar algunos años que la aprendan, cuya dificultad aprende sólo el que con suficiencia ha aprendido alguna.

Ultimamente pide y suplica a V.M. que en caso que haya de haber mudanza o postura en las dichas Doctrinas, el suplicante en nombre de su provincia las toma por el tanto que otro bajare. Y si V.M. se sirviere de quitar desde luego el estipendio, con toda sumisión acepta el mandato de V.M., que toda su provincia está muy sujeta y obediente, y servir de valde las dichas Doctrinas: porque hijos engendrados con tanto dolor, cualquiera interés es poco para su rescate. Otro sí, pide y suplica a V.M. se sirva mandar que el Consejo Real de Indias mande hacer información de todos los puntos que contiene este Memorial. Y si fuere necesario para mayor satisfacción de las verdades que representa, se remita este Memorial al Virrey del Perú y a la Audiencia de los 
Charcas: para que por él como por interrogatorio, sean examinados los testigos: Que en ello recibirá merced etc."

\section{Memorial al Virrey del Perú.}

Requiere e implora armas de fuego para las reducciones debido a la peligrosa situación causada por los bandeirantes.

Texto: I. Original I. en el Archivo General de Índia, 76-3-8-PARA.

II. Copia em el Archivo General de la Nación Argentina, Buenos Aires, Archivo, Compañía de Jesús, Reales Identificaciones, $\mathrm{N}^{\circ} 12$.

III. Copia más completa em la Colección Gondra de la Universidade de Texas, Austin, E.U.A., daque este documento bajo el Nº 657, Gondra-Casteñeda, 1952.

Impresión: Pastells 2, pp.108-111.

Edición: Se edita el texto que transcribe Pastells, con ortografia actualizada y notas.

Destinatario: El Virrey del Perú.

Fecha: Lima, 8 de noviembre de 1644.

Bibliografia: Storni, Montoya, nº106 de p.435,; Furlong, Montoya, p.135, №38.

Autores: PASTELLS 2, pp.108-111; HERNANDEZ 1, pp.526-528; VIANNA 3, p.434437.

Texto

\section{Memorial al Virrey}

"Antonio Ruiz de Montoya, Procurador General de la Compañía de Jesús de la Provincia del Paraguay, en que dice que él y sus compañeros fundaron muchas poblaciones de indios infieles, reduciéndolos a pueblo a costa de la sangre que derramaron siete compañeros suyos, con atroces martirios que les dieron los gentiles; y estando pacificados y adoctrinados, fueron invadidos por los portugueses del Brasil, casi sin resistencia de los indios, por no tener otras armas que flechas de cañuelas; y deshicieron en la Provincia de Guairá, Obispado del Paraguay, 11 reducciones de 700, de 800 y de 1000 indios. Y en la Provincia del Tape, jurisdicción de Buenos Aires, destruyendo otras tantas; descuartizando indios con alfanjes y machetes, pasando mucha cantidad de infantes a cuchillo en los mismos pechos de sus madres; dando con otros en las puertas y árboles, e hiriendo malamente a dos religiosos que tenían a cargo aquellas iglesias; quemaron los templos, desterrando de ellos el Venerabilísimo Sacramento del altar; y para mayor mofa de nuestra sagrada a religión, las sacristías y los mismos altares, donde por muchos años se había celebrado el sacrificio de la misa, destinaron para lugar de sus inmundicias corporales; haciendo y cometiendo otros delitos tan enormes, que dieron claro testimonio de ser judíos herejes.

Y habiendo acudido, en nombre de su provincia, a los pies de S.A. con informaciones jurídicas, que puso en sus Reales manos, con cartas del Sr. D. Juan de Lizarazu, Presidente entonces de los Charcas, y de los Sres. Obispos y Gobernadores, que apretadamente pedían el remedio, cautelando los inconvenientes que hoy se experimentan; y visto y examinados estos papeles por una Junta particular, que para el 
caso se señaló: erigió S.M. para el remedio un nuevo Obispado y una Inquisición en la ciudad de Río de Janeiro, en el Brasil, de donde emanaban todos estos daños y mandó ejecutar todos los medios que él propuso, con otros que a la dicha Junta pareció añadir, ordenándolo en largos capítulos de una carta de S.M.; y mandó despachar al Sr. D. Jorge Macareñas, que entonces era Virrey del Brasil, la ejecución de todo.

Y estando ya el nuevo Sr. Obispo e Inquisidor en Lisboa para hacer viaje a su iglesia y poner en ejecución las órdenes y mandatos reales; y él de partida para la dicha ciudad, para ir acompañando el dicho señor Obispo, para que con su autoridad y la del Sr. Virrey se le entregasen todos los indios que dichos portugueses habían llevado cautivos; sucedió la rebelión y alzamiento de Portugal, con que no tuvieron efecto dichas órdenes. A cuya causa volvió (el P. Ruiz de Montoya) a la Corte y a los pies de S.M., que mandó se diesen arbitrios para el remedio. Uno de ellos, y el más eficaz fue, que S.M. mandase se diesen armas de fuego a los indios, que la Compañía había escapado de tan pernicioso enemigo, ya declarado; y pusiese presidios de los mismos indios, que en 25 poblaciones tenían y hacían una buena provincia; los cuales era necesaario usasen de dichas armas, así para su defensa como para poder impedir el paso a los enemigos, que ya con el nuevo alzamiento pretendían conquistar toda la provincia del Paraguay, y por allí bajar al puerto de Buenos Aires; lo cual habían ya empezado a hacer en tiempo que se reputarían por vasallos de V.M., seis años antes del alzamiento, destruyendo la provincia de Guairá; en que asolaron tres ciudades españolas, Ciudad Real, la ciudad de Jerez y Villa Rica, de donde se llevaron muchos pueblos de indios que servían a las dichas ciudades y gran parte de los vecinos, quellevaron por trofeo, dejando toda aquella latísima Sierra yerma, quedó reducido con la pérdida de dichas tres ciudades a solo la ciudad de la Asunción y un lugar pequeño en que se juntaron algunos vecinos de las cuidades destruídas, cuyo número no llegaría a 500 y de esos, muchos inútiles para la guerra y no pocos de ellos portugueses.

La cual proposición, vista y examinada por una Junta particular y por la de guerra de Estado, se sirvió S.M. de remitirla a su excelencia para que en esta razón se ejecutase lo que más conviniese a su Real servicio, la cual tiene su excelencia en su poder.

Y habiendo vuelto dichos portugueses, en número de 500, con 200 indios tupís, contra dichas reducciones, y visto por el Gobernador del Paraguay la poca o ninguna defensa que tenían, les dio algunas escopetas y con otras pocas que en tan corta Sierra pudieron hallar los Padres, se pusieron en defensa, acaudillándolos el Hermano Antón Bernal, religioso de la Compañía, que en Chile, siendo soldado, ocupó con su valor muy honrosos puestos, y otros religiosos legos que pusieron sus vidas a tan conocidos riesgos; mataron 14 portugueses y prendieron 10, que llevaron al gobernador, quitándoles cerca de 2000 gentiles, que ya habían cautivado para llevar a vender al Brasil; y con esto, en la Corte se dijo que de 500 portugueses no habían escapado con vida más que 30; porque, atemorizados, se acogieron a los montes, donde perecieron; de que D. Pedro Esteban Dávila, caballero del Orden de Santiago, Gobernador que fue del puerto de Buenos Aires, llevaba relación a S.M. en que claramente consta de este suceso y utilidades de estas armas; y se ha experimentado en otras ocasiones en que volvieron dichos portugeses y principalmente en la última entrada que hicieron a la venganza de sus malos sucesos pasados, en que les mataron los indios 60 y puestos los demás en huída; no les siguieron al alcance por haberles faltado munición, y les quitaron todos los indios que traían en su ayuda; de que S.M. teni,ndose por bien servido, les concedió que en diez años no pagasen tributo ni sirvan: con que están muy favorecidos y deseosos de acudir a su Real servicio. 
Y teniendo aviso de los religiosos de aquella provincia, que dichos portugueses venían con ánimo de apoderarse de la ciudad de la Asunción, confiados de hallar en ella gente de su nación que los ayudasen, donde no se duda se haríban señores de toda la tierra y de la de Tucumán, donde están recogidos los portugueses de aquellas provincias:

A Su Excelencia pide y suplica se sirva de ver este negocio con la atención que pide su gravedad, de que depende el logro y quietud de estos reinos y de mandarle dar las armas necesarias para resistir a 2000 portugueses y a 2000 tupíes, que también muchos manejan armas de fuego; y mande que por ahora, vista la apretura y falta de ellas, por haber Su Excelencia socorrido tantos presidios y armado tantos soldados; se le den 500 cañones, 70 botijas de pólvora y otros tantos quintales de plomo o lo que Su Excelencia fuere servido, para que por Santiago de Chile pueda pasar a ladicha provincia, si no es que sea de menos costa, que en Jujuy se dé el plomo y en Tucumán la pólvora y así mismo que los Oficiales Reales le den el avío necesario para ponerlo en el Paraguay, que en ello serán servidas ambas Majestades.

\section{Antonio Ruiz [de Montoya]}

\section{Memorial al Virrey del Perú.}

Urge al Virrey la remesa de armas para el Paraguay.

Texto: I. Archivo General de Índia, 76-3-8-A.

II.Archivo General de la Nación Argentina, Buenos Aires, Archivo Reales Identificaciones, Nº14. 65. Gondra Castañeda, 1952, Nº 661.

Impressão: Hernández 1, pp.531-532.

Edición: Se edita el texto transcripto por el P. Pablo Hernandez con ortografia actualizada y notas.

Destinatario: El Virrey de Perú D. Josef de Càceres y Ulloa.

Data: 1646.

Bibliografia: Storni, Montoya, p.435, Nº100,; Furlong, Montoya, p.136, No41.

Autores: Hernández 1, pp.531-532; Pastell 2, pp.111-112.

Texto

Memorial al Virrey

"EXCELENTISIMO SR.: EL P. ANTONIO RUIZ DE MONTOYA, de la Compañía de Jesús y Procurador general de la del Paraguay, Dice: que V.E. con parecer del Acuerdo general de Hacienda de veinte y tres Marzo del año pasado de seiscientos y cuarenta y cinco, fue servido de ordenar se dé hasta ciento y cincuenta bocas de fuego, setenta botijas de pólvora y setenta quintales de plomo, para que se lleve a las provincias del Paraguay, y para la defensa de aquellos indios, quetan afligidos se hallan de los portugueses del Brasil. Y porque de la detencicn de este despacho puede resultar a dichos indios muy gran perjuicio, por hallarse indefensos como es notorio, y correr riesgo sus personas y sus vidas: 
A V.E. PIDE y suplica que en conformidad de lo resuelto en el dicho Acuerdo general, se sirva de mandar despachar provisión para que de la sala de armas de esta ciudad, o del puerto del Callao, se saquen las bocas de fuego que a V.E. pareciere, y que se embarquen en un navío que de próximo está de partida para el puerto de Arica, juntamente con las setenta botijas de pólvora; y que vaya registrado y consignado a poder de los Oficiales Reales del dicho puerto de Arica, para que, recibido que lo hayan, remitan las dichas bocas de fuego en los cajones que se hicieren para ellas; y que la pólvora la despachen en la forma que lo quelo hicieron en la ocasión que V.E. fue servido de remitir estos géneros para el socorro de Buenos Aires; y que guarden el mismo orden para lo tocante a las dichas bocas de fuego y pólvora, fletándolo a costa dela Real Hacienda, hasta que se entregue a los Oficiales reales de Potosí; y ellos hagan lo mismo hasta ponerlo en las Reducciones de la Compañía de Jesús del Paraguay.

Y OTRO SI suplica a V.E. se sirva de despachar provisión para que en la ciudad de la Plata se saquen las bocas de fuego que faltaren de entregar en cumplimiento de las ciento y cincuenta que se han de dar, de las que por cuenta de S.M. están en la dicha ciudad, y que los Oficiales de Potosí las despachen con las demás bocas de fuego referidas; y que asimismo los Oficiales de la villa de Oruro remitan a los de Potosí los setenta quintales de plomo que están mandados dar, para que todo se remita en la forma referida a poder de los dichos Padres de la Compañía, como está mandado por el dicho Acuerdo.

EN LO CUAL HARA V.E. muy gran servicio a Dios nuestro Señor y a S.M., y el suplicante recibir la merced que espera de la grandeza de V.E."

\section{ANTONIO RUIZ DE MONTOYA}

\section{Memorial al Virrey del Perú.}

Impresión: Trelles Manuel Ricardo, Anexa a la Memoria sobre la cuestión de Límites entre la República Argentina y el Paraguay, Publicación Oficial. Buenos Aires, Imprenta del Comercio del Plata, Victoria 87, 1867. pp.30-34.

Edición: Se edita el texto que transcribe Manuel Trelles con ortografía actualizada y notas.

Destinatario: El Virrey del Perú, Cuenta de Salvatierra.

Fecha: Lima, antes de 16 de marzo de 1649.

Bibliografia: Storni, Montoya, $n^{\circ} 117$ de p.435,; Furlong, Montoya, n⿳403 de p.137,; Cardozo 1, n⿳05 de p.245.

Autores: Pastells 2, pp. 201-202.

Texto

\section{Memorial al Virrey}

"Excelentísimo Señor. El Padre Antonio Ruiz de Montoya de la Compañía de Jesús, Rector del Colegio de la Asunción y Procurador General de la Provincia del Paraguay como consta del poder que tiene presentado en el real acuerdo dice: Que su religión redujo en dicha provincia al evangelio y obediencia de Su Majestad, con muerte de nueve sacerdotes, que padecieron glorioso martirio, veinte y cuatro poblaciones de 
gentiles, que derramados y sin pueblos vivían en las Provincias del Uruguay, Tape y Río Paraná, y en la Provincia del Itatí hizo tres poblaciones así mismo de gentiles, confinantes a la Provincia de Santa Cruz de la Sierra, que hoy doctrinan en paz más de cincuenta sacerdotes de la misma Compañía de Jesús, los cuales indios han tenido de algunos años a esta parte reñidos encuentros con los rebeldes portugueses, que con pertinacia hasta hoy intentan la conquista de aquellas tierras, para hacer pie en este Perú de los cuales han conseguido insignes victorias, matando mucho número de ellos y ahuyent ndolos de nuestros confines, en muchas ocasiones, varias veces han salido auxiliando a los españoles a la pacificación de la tierra contra otros indios rebeldes, con toda fidelidad y logro de victorias que han alcanzado y todo a su costa, sin haber tenido socorro alguno, antes han comprado de su hacienda más de seiscientas bocas de fuego y municiones, a cuyo valor se debe no estar aquella tierra en poder de dichos rebeldes portugueses, de los cuales se tienen frecuentes avisos de la prevención que hacen para volver a sujetar la tierra a cuya causa viven dichos indios con vigilante ejercicio de las armas, como es notorio y consta de las certificaciones que presenta, de todo lo cual siendo Su Majestad informado y dándose por bien servido, se sirvió mandar despachar la cédula que presenta, en que manda se le haga merced por vía de gratificación y por que a dichos indios no se les ha puesto hasta hoy tributo alguno teniendo Su Majestad atención a que habiédose resistido en su gentilidad contra la fe y obediencia de $\mathrm{Su}$ Majestad, por el horror que tuvieron a las vejaciones y malos tratamientos que recibían comunmente los indios de los españoles en este reino, se redujeron fiados en la palabra que en nombre de Su Majestad se les dio de que no serían encomendados ni se les impondría el yugo intolerable del servicio personal, lo cual a instancia del suplicante se sirvió Su Majestad confirmar por una su real cédula y porque si a dichos indios se les pusiera tributo y mitas sobrecargándolos al peso que hoy tienen de mantener la guerra contra los rebeldes, podrían temerse irremediables daños teniendo sobre si cobradores y esactores que con impiedad los molesten en tiempo que por su fidelidad y servicios debían ser premidados, con que se les podría dar ocasión de novedades y podría ser se confederasen con el rebelde portugués, su confinante, que solicita su amistad con promesas e intereses, de que resultarían muy graves inquietudes a todo este reino, y notable deservicio a Su Majestad, de que hace advertencia el suplicante, porque si en algún tiempo sucediese algún disturbio no se impute a descuido o inadvertencia de su religión, en el real servicio a Vuestra Excelencia pido y suplico se sirva mandar, en ejecución de la real cédula de que hace presentación, se sirva declarar los dichos indios por vasallos de Su Majestad y pertenecientes a su Real Corona, pues a sus reales espensas y su real mandato fueron conquistados por sclo el evangelio y doctrinados hasta hoy.

Y así mismo por presidarios de aquel presidio, a quien el Señor Marqués de Mansera, antecesor de Vuestra Excelencia, en virtud de una real cédula que a peticiøn del suplicante se sirvió Su Majestad mandar despacharles, ha socorrido con armas de fuego y municiones, con que están hoy más animados a proseguir en el real servicio, y así mismo se sirva Vuestra Excelencia de declararlos por libres de tributos y mitas en conformidad de la dicha real cédula con que animados, puedan proseguir en el servicio que actualmente estan haciendo a Su Majestad y no ser mucha esta merced pues hay muchos y notables ejemplares: en el Reino de Chile tiene Su Majestad Compañía de soldados indios, que no solo no pagan tributos ni mitas, como es público, antes $\mathrm{Su}$ Majestad, les da jornales de soldados como a los españoles en la ciudad del Cuzco viven así mismo libres de tributo y mitas los indios Cañares, en premio de haberse mostrado leales en la primera conquista de estos reinos; en el Reino de Tierra firme ha dado 
libertad y excensión de tributos y mitas aquella Real Audiencia a los indios de la Provincias de Guaiví Darien, solo por haberse convertido a la fe, y Su Majestad con su real liberalidad les da doctrina a sus reales espensas, y en el reino de Chile el Señor Marquéz de Mansera dio en su real nombre el mismo privilegio al cacique Manqui ante a sus hijos y vasallos, por haber dado la paz y sujetándose a la corona y si dichos indios por las dichas razones han sido y son premiados, con muchas más razón merecen serlo los de dichas Provincias del Paraná y Tape, Itatines, pues demás de haber dado paso al evangelio y vasallaje a Su Majestad. Le estan actualmente sirviendo con su hacienda y vida en defensa de sus reinos y hacen los Señores Reyes esta merced dice el Doctor Don Juan de Solorsano (DE JURE INDIARUM) que est en uso et cadem de causa dize solent tributare mitis indis ant moderatius taxariquia justa allios barbaros et infidelissivi et nobis habitant et fines nostros juacara et armis defendunt (Juan Sator tom.2 de Jure Indiarum guber. L1, cap. 19,n.71); y cuando demás del servicio que hoy están haciendo a Su Majestad en defender la tierra, dichos indos, pareciera convenir ponerles algún tributo en reconocimiento del debido vasallaje, atendiendo a su pobreza y falta de oro y plata, que no lo hay, y no lo es conocida en aquella tierra, se les podría poner de tributo un peso de ocho reales en cada un año, a cada un indio, de los que conforme a su ordenanzas reales deban pagar tributo y no en especie de sus cosechas que son bien cortas, por evitar inconvenientes que podrán causar los cobradores y los acarreos y gastos que es fuerza hacer con las dichas especies y frutos de la tierra, que es fuerza trasnportarlos más de doscientas leguas al puerto de Buenos Aires o a la gobernación del Tucumán, para que tengan algún valor, con que correr por cuenta de los indios la pérdida o ganancia y se evitarán cuentas y supercherías con los cobradores, y para que éste nuevo tributo se entable en paz y sin riesgo de alborotos, parece convendrá que pues, está a cargo de los Oficiales Reales de Buenos Aires cobrar las haciendas reales y la cobranza de este tributo les compete está también a su cargo del Tesorero y Contador o de cualquiera de ellos hacer los padrones y visita de dichos indios y recibir dichos tributos en reales, y no esté a cargo de los gobernadores, porque estos atendiendo a sus intereses y al limitado tiempo de su gobierno, no se paran en molestar los indios con que podrá ser procuren arrojar de si este yugo como gente nueva y que hasta ahora no se le ha puesto, de que será Su Majestad muy bien servido, antes se sirva Vuestra Excelencia prohibirles a dichos Gobernadores al ocuparlos en sus trajines y ganancias mandando que, con el dicho tributo y cargo defender la tierra queden dichos indios libres de todo género de mita, pues Su Majestad los tiene ya reservados del servicio personal por una nueva y especial cédula que se sirvió mandar despachar a petición del suplicante, y así mismo convendrá encargar mucho a los dichos Oficiales Reales la blandura y tiento con que se deben ir entablando estos tributos por los gravísimos inconvenientes que se deben cautelar, por ser materia odiosa y en gente nueva no habituada a yugo, todo lo cual propone el suplicante con atención al real servicio y pide y suplica a Vuestra Excelencia se sirva de mandar ejecutar lo que fuera de mayor gloria de Dios y servicio de Su Majestad.

ANTONIO RUIZ DE MONTOYA 


\section{Bibliografía}

Cadogan, León (1959). Ayru Rapytä. Sâo Paulo.

Carbonell de Masy SI., Rafael. (1985). "La contribución de Ruiz de Montoya al desarrollo económico de las reducciones". Anais do VI Simposio Nacional de Estudos Missioneiros. Santa Rosa. R.S. Brasil: Facultad de Filosofía. Ciencias e Letras. Dom Bosco.

Cardozo, Efraim (1979). Historia paraguaya I. Paraguay indígena, español y jesuita. México: Instituto Panamericano de Geografía e Historia. Comisión de Historia 83. Historiografía la V. México.

Charlevoix SI, Pedro Francisco Javier (1912). Historia del Paraguay escrita en francés por el P. .... Con anotaciones y correcciones latinas del P. Muriel. Traducida al castellano por el P. Pablo Hernández. Tomo 2. Madrid: Librería de Victoriano Suárez.

Cortesâo, Jaime (1951). Colección De Angelis, Jesuitas e Bandeirantes no Guairá T.1 (1549-1640), Tomo 1. Río de Janeiro: Biblioteca Nacional, Diviâo de obras raras e publicaçôes.

Furlong SI, Guillermo (1964). Antonio Ruiz de Montoya y su carta a Comental (1645). Buenos Aires: Ediciones Theoría.

Hernández, Pablo (1912). "Un misionero jesuita del Paraguay en la corte de Felipe $I V$ ”. Razón y Fe, $\mathrm{N}^{\circ} 33$. Madrid.

(1913) Organización social de las Doctrinas Guaranies de la Compañía de Jesús. 2 tomos. Barcelona: Gustavo Gili Editor.

Jarque SI, Francisco (1900). Ruiz de Montoya en Indias. 4 tomos (1608-1652). Madrid: Victoriano Suárez editor. Leonhardt SI, Carlos. (1927-1929). Documentos para la Historia Argentina, Tomos XIX-XX. Iglesia Cartas Anuas de la Provincia del Paraguay, Chile y Tucumán, de la Compañía de Jesús. Con advertencia de Emilio Ravignani e introducción del P. Carlos Leonhardt. Buenos Aires. (Vol. 1, 1609-1614. Vol. 2, 1615-1637). Buenos Aires: Talleres S.A. Casa Jacobo Peuser.

Lozano SI, Pedro (1754-1755). Historia de la Compañía de Jesús en la Provincia del Paraguay, 2 tomos. Madrid: Imprenta de la Viuda de Manuel Fernández, y del Supremo Consejo de la Inquisición.

Maeder, Ernesto (1984). Cartas Anuas de la Provincia Jesuítica del Paraguay, Cartas Anuas del Paraguay (1637-1639). Buenos Aires: CECIC, Fundación para la Educación la Ciencia y la Cultura.

Melia SJ, Bartomeu (1985). "Los dos primeros Memoriales de Montoya en Madrid". Anais do VI Simposio Nacional de Estudos Missioneiros.

(1989) Montoya e as Reduçoes num tempo de fronteiras. Facultade de Filosofía, Ciencias e Letras Dom Bosco.

(1984) “Missáo por Reducáo”. En: Estudos Leopoldenses. Vol. 25, № 110. Universidade do Vale do Rio dos Sinos, Sáo Leopoldo. Brasil. Catálogo del los jesuítas de la provincia del Paraguay (Cuenca del Plata) 1585-1768. Roma. 
Pastells SI, Pablo (1912). Historia de la Compañía de Jesús en la Provincia del Paraguay (Argentina, Paraguay, Uruguay, Perú, Bolivia y Brasil) según los documentos originales del Archivo General de Indias. Tomo 1. Madrid: Librería General de Victoriano Suárez.

Storni SI, Hugo (1984). Antonio Ruiz de Montoya en Indias. Archivum Historicum Societatis Jesus. Vol. LIII.

Vargas Ugarte SI, Rubén - Castillo, Francisco del (1960). Un Místico del Siglo XVII. Autobiografía del Padre Francisco del Castillo de la Compañía de Jesús. Lima: Imp. Gil.

Tormo Sanz, Leandro y Blanco, Ricardo Román (1989). Montoya y su lucha por la libertad de los indios. Batalla de Mbororé. Sáo Paulo: Enveloart Editora e Gráfica Ltda. 